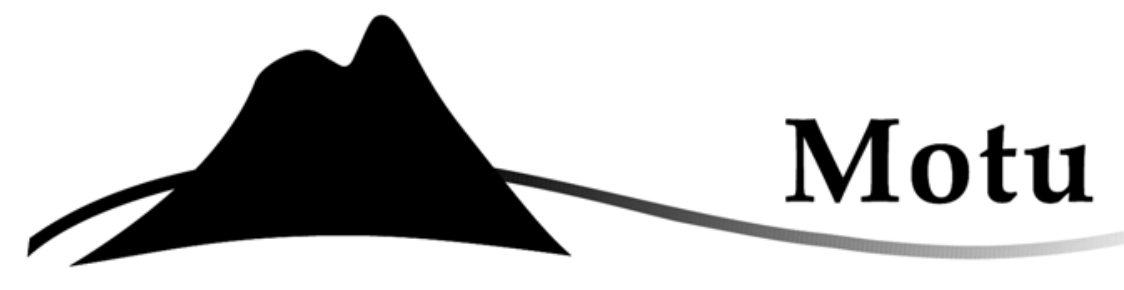

\title{
An Auckland Land Value Annual Database
}

Arthur Grimes \& Yun Liang

Motu Working Paper 07-04

Motu Economic and Public Policy Research

April 2007 
Author contact details

Arthur Grimes

Motu Economic and Public Policy Research

arthur.grimes@motu.org.nz

Yun Liang

Motu Economic and Public Policy Research

yun.liang@motu.org.nz

\section{Acknowledgements}

We thank the Foundation for Research, Science and Technology (programme on Infrastructure) for providing the funding to make this research possible. We also thank Quotable Value New Zealand for providing the data on which this research is based. Finally we thank our colleagues in the programme, David Mare, Steven Stillman, Philip McCann and Jacques Poot for comments on our initial thoughts on the construction of this database.

Motu Economic and Public Policy Research

PO Box 24390

Wellington

New Zealand

Email info@motu.org.nz

Telephone +64-4-939-4250

Website www.motu.org.nz

(C) 2007 Motu Economic and Public Policy Research Trust. All rights reserved. No portion of this paper may be reproduced without permission of the authors. Motu Working Papers are research materials circulated by their authors for purposes of information and discussion. They have not necessarily undergone formal peer review or editorial treatment. ISSN 1176-2667. 


\section{Abstract}

We construct an annual land value database at the meshblock (MB) level for the Greater Auckland region. The database provides a resource for research work that requires land values (per hectare) across the region. The data is based on valuation records sourced from Quotable Value New Zealand (QVNZ). It covers seven Territorial Authorities (TAs): Rodney District, North Shore City, Waitakere City, Auckland City, Manukau City, Papakura District and Franklin District. The valuation data, which are generally available on a three-yearly cycle for each TA, are interpolated to annual frequency using sale price data for residential vacant land at the TA level. The resulting database extends from 19902003 (annually) for MBs in all seven TAs. In some TAs, data are available for slightly longer periods depending on source data availability.

JEL classification

C81; Q24; R12

Keywords

Auckland; Land values; Database 



\section{Contents}

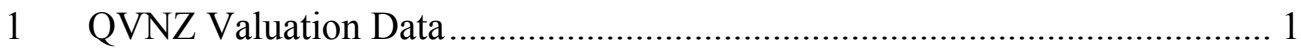

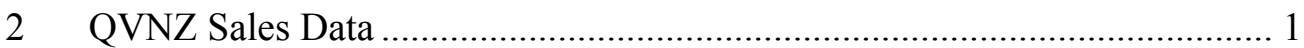

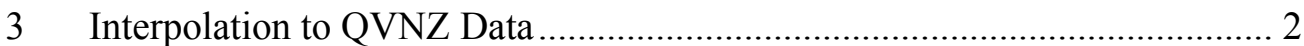

3.1 General Annual Interpolation Method ................................................... 3

3.2 Adjustments Before Interpolation .................................................... 4

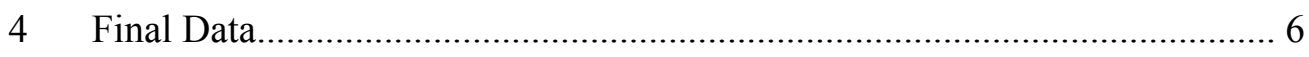

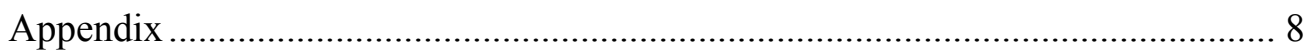





\section{Table of figures}

Figure 1 Relative land price in North Shore City in 1988 ................................. 14

Figure 2 Relative land price in Waitakere City in the first 2 cycle years ............. 15

Figure 3 Relative Land Price by MB and year in Greater Auckland ................... 17 



\section{Tables}

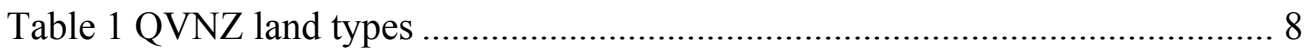

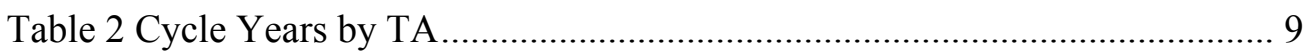

Table 3 MBs in Greater Auckland that do not have any valuation data .............. 10

Table 4 MBs with Cleaned Data, and Corresponding Adjustments...............11 



\section{$1 \quad$ QVNZ Valuation Data}

Quotable Value New Zealand (QVNZ) provides property valuation data for each year starting in June from 1990 to 2006 . QVNZ provides the capital value, ${ }^{1}$ land value, ${ }^{2}$ improved value ${ }^{3}$ of each property, as well as recording its land area and type. In general, valuations in Territorial Authorities (TA) are carried out on a three-year cycle unless it is specifically requested that a property be re-valued at an earlier date. ${ }^{4}$ The records for each property are kept until new valuations become available and they can be updated.

The valuation data used in this project is measured at meshblock (MB) level, on Statistics New Zealand's (SNZ) 2001 boundaries. For each year, QVNZ assigns the most recent valuation to a property, and then aggregates all the properties at the MB level. For each $\mathrm{MB}$, the valuation database contains the total number of assessments, the total capital value of all assessments, the total land value of all assessments, the total improved value of all assessments, and the total land area assessed for 36 categories of land types. ${ }^{5}$

\section{QVNZ Sales Data}

Another QVNZ dataset used in this project is sales price data at TA level. The sales data contains the same categories of land type as in the valuation data, but contains records for the properties sold each year instead of all properties. For each TA and each land type, the QVNZ sales database records the number of sales, the total capital values of all sales, the total land value of all sales, the total improved value of all sales, the total, mean and median sale prices for all sales, and the total land area of all sales. This information is available annually for each June year from 1981 to 2006.

\footnotetext{
${ }^{1}$ Defined as the sum that an owner's estate or interest in the land, if unencumbered by any mortgage or other charge, might be expected to realise at the time of valuation if offered for sale on such reasonable terms and conditions as a bona fide seller might be expected to require. Does not include chattels, stock, plant or machinery which may normally be included when properties are sold.

${ }^{2}$ Defined as the sum that an owner's estate or interest in the land, if unencumbered by any mortgage or other charge, might be expected to realise at the time of valuation if: (a) offered for sale on such reasonable terms and conditions as a bona fide seller might be expected to impose; and (b) no improvements had been made on the land.

${ }^{3}$ Defined as the difference between the capital value and the land value of that type of property.

${ }^{4}$ According to a private communication between Steve Stillman and Richard Deakin (QVNZ), the following situations can result in a revaluation: "the property owner has requested a revaluation, a building consent has been issued for the property, the property has been subdivided or has otherwise changed its usage category, or a mistake has been found in the record."

${ }^{5}$ The 36 raw land types are listed in Table 1 of the Appendix.
} 


\section{$3 \quad$ Interpolation to QVNZ Data}

In this project, we focus on the seven TAs across Greater Auckland: Rodney District; North Shore City; Waitakere City; Auckland City; Manukau City; Papakura District; and Franklin District. ${ }^{6}$ We focus on the aggregated land value for each MB (i.e. we do not disaggregate the land types).

Each yearly raw extract from QVNZ repeats valuations for each MB until the new valuation becomes available. In the extract, the year in which the valuation was completed is recorded with the valuation. We define the valuation year in which most properties were valued in each TA as the cycle year for that TA. For example, in the 2000 valuation extract, the recorded valuation years in Rodney District were 1997, 1998 and 1999. 1998 was the valuation year in which the highest number of properties were valued, so we have defined it as a cycle year in Rodney. We repeated this for every yearly raw extract and ended up with 6 or 7 cycle years for each TA in Greater Auckland. ${ }^{7}$ In these 7 TAs, not all the cycle years are 3 years apart, but none has a valuation cycle that exceeds 3 years. ${ }^{8}$

We require one record for a MB within each cycle. Therefore, we used the extracts one year after the actual cycle years to ensure the valuations completed in the cycle years are included. If a property was valued in a cycle year, we left its value as it appeared in the dataset. For all properties that were valued off cycle (for the preceding one or two years), we treated them as if they had been valued in the cycle year. For example, as mentioned above, 1998 is one of the cycle years in the Rodney District. In order to ascertain the district's 1998 valuation data, we used the 1999 extract for Rodney. In that extract, the valuation years are 1996, 1997 (preceding two years) or 1998 (the cycle year), so we treated the valuations as if they were all done in 1998 and aggregated to one record for each MB. There were three reasons for doing this:

- No information was available to identify the properties that were valued in off-cycle years. We could not therefore adjust the records in cycle years by updating values for corresponding properties.

\footnotetext{
${ }^{6}$ The Auckland Region only contains a proportion of the Franklin District. We include the whole of Franklin District in this project and define the 7 TAs as "Greater Auckland".

${ }^{7}$ This method was applied to both the data with detailed raw land types and the aggregated data, and the cycle years are always the same.

${ }^{8}$ See Table 2 in the Appendix for a list of cycle years for each TA in Greater Auckland.
} 
- The off-cycle valuations in the chosen raw extract were all done after the last valuation year, which was 1995 in the example provided above. Thus, these valuations could not be recorded in the preceding cycle; instead, they had to appear in the following cycle which, in this example, occurred in 1998.

- The number of assessments and values from off-cycle valuations are very small. We included them in the database, so that the information would be complete.

This method gives us valuation data for each TA by cycle year. Based on the cycleyear datasets for the 7 TAs, we then interpolated between the cycle years to gain an annual database for land price per hectare for each MB across Greater Auckland. The main reason for doing so is that cycle years differ across TAs, so without interpolation to annual frequency we could not directly compare values in one TA with those from another for the same period.

\subsection{General Annual Interpolation Method}

The method used for between cycle interpolations is as follows (where $\mathrm{j}$ refers to the specific meshblock; A refers to the TA in which meshblock $\mathrm{j}$ is situated ${ }^{9} \mathrm{t}$ refers to year):

Let:

$\mathrm{L}_{\mathrm{jt}}=$ aggregated land value for properties in $\mathrm{j}$;

$\mathrm{L}_{\mathrm{At}}=$ aggregated land value for properties in $\mathrm{A}$;

$\mathrm{S}_{\mathrm{At}}=$ median sale price of residential vacant land in $\mathrm{A} ;{ }^{10}$

We observe $\mathrm{L}_{\mathrm{jt}}$ and $\mathrm{L}_{\mathrm{At}}$ periodically (e.g. in $\mathrm{t}=1, \ldots 4, \ldots 7, \ldots$ ); we observe $\mathrm{S}_{\mathrm{At}}$ annually ( $\mathrm{t}=1$, $2,3,4, \ldots)$.

Let:

$\beta_{\mathrm{jt}}=\mathrm{L}_{\mathrm{j} t} / \mathrm{L}_{\mathrm{At}} \quad$ (observed periodically)

$\gamma_{\mathrm{jt}}=\mathrm{L}_{\mathrm{At}} / \mathrm{S}_{\mathrm{At}} \quad$ (observed periodically)

\footnotetext{
${ }^{9}$ TAs are used as the spatial units for sale prices since there are generally a large number of annual sales within a TA and thus the observed median price is not too noisy. At the same time, a TA is reasonably 'local' so it can be used to approximate general property price movements in the relevant area.

${ }^{10}$ The purpose for using the median sales price from residential vacant land is that there is always a reasonable number of sales for this type of land no matter which TAs are examined. This results in a reasonably smooth sales price trend, so it is the best indicator of changes in price between years. As well as this, it is vacant land, so it gives a good estimate of the land price.
} 
Hence:

$\mathrm{L}_{\mathrm{jt}}=\alpha_{\mathrm{jt}} \cdot \mathrm{S}_{\mathrm{At}} \quad\left(\right.$ where $\left.\alpha_{\mathrm{jt}}=\beta_{\mathrm{jt}} \cdot \gamma_{\mathrm{jt}}\right)$

We hypothesise that the ratios, $\beta_{\mathrm{jt}}$ and $\gamma_{\mathrm{jt}}$, will evolve relatively smoothly over time since they are the ratios of two nominal variables and are therefore unaffected by general changes in nominal prices and values. Thus, we can assume that $\alpha_{j t}$ will also evolve reasonably smoothly over time. Accordingly, we linearly interpolate $\alpha_{\mathrm{jt}}$ between valuation years (no matter what the valuation frequency) and apply this factor to the observed $\mathrm{S}_{\mathrm{At}}$ in order to obtain estimated annual observations. Valuations will still move sharply between years in cases where $\mathrm{S}_{\mathrm{At}}$ changes significantly on an annual basis, so general property price movements in the area will be reflected in our valuation estimates. ${ }^{11}$

\subsection{Adjustments Before Interpolation}

Before applying this method, we made some adjustments to the raw data. This was necessary because the valuation data received from QVNZ occasionally had some reporting flaws (mostly sporadic under-reporting of values for a specific land type - e.g. commercial land in 1998 for a particular MB). As well as this, some MBs were not valued in all cycle years.

There are $8803 \mathrm{MBs}$ in Greater Auckland according to the boundaries defined in 2001. Of these $8803 \mathrm{MBs}, 116$ have no valuation information recorded for any year. These 116 MBs usually cover lakes, islands or have no properties on them. We therefore excluded these MBs from our analysis. ${ }^{12}$ There are 1785 MBs with missing valuations in early cycles, 1 with a missing valuation in the last cycle year and 2 with missing valuations in both the beginning cycle years and the end cycle year. For these MBs, we only interpolate between the available cycles, other missing valuations remain as missing data points. There are $7 \mathrm{MBs}$ with missing valuations in the middle part of the periods, so we have done the interpolation using the neighbouring cycle years (i.e. over 6 years instead of 3 years).

We then examined the ratio between the MB level aggregated land values $\left(\mathrm{L}_{\mathrm{j}}\right.$, labelled as lv_mb in our database) and the TA level aggregated land values ( $\mathrm{L}_{\mathrm{At}}$, labelled as

\footnotetext{
${ }^{11}$ We tested this method against the alternative of linear interpolation on cycle year observations. We did the comparison using neighbouring cycle year observations (i.e. interpolation over 6 year periods) and found that this method gave a closer match to the known data points than did linear interpolation.
} 
lv_ta in our database), which is the $\beta_{\mathrm{jt}}$ mentioned above (labelled as $1 \mathrm{v}$.mbta in our database) to verify its smoothness. We checked for obvious data flaws at the MB level as follows:

First, we identified any MB that had a between-cycle change of $\beta_{\mathrm{jt}}$ satisfying one of the following situations:

- a drop of over $20 \%$ and then an increase of over $20 \%$ in the next cycle; or

- $\quad$ an increase of over $20 \%$ and then a drop of over $20 \%$ in the next cycle

and treated this $\mathrm{MB}$ as suspicious. In this step, we found that because the number of MBs being valued every year within a TA fluctuates, some of the significant changes which are discernable in lv_mbta do not indicate actual data flaws. This situation is most prevalent in North Shore City and Waitakere City. In North Shore City, only 571 MBs out of 1424 were valued in the first cycle year - 1988. In 1990, the number of MBs with valuation data increased to 1341, stabilising from that point on. Therefore, it was not reasonable to compare lv_mbta for the 571 MBs valued in 1988 with this variable in later years because it would show a significant drop in the variable. So in this case, we grouped the initial $571 \mathrm{MBs}$ together and calculated the ratio between the MB level land value and the aggregated land value for the $571 \mathrm{MBs}$ from 1988 (first cycle) to 2005 (last cycle) and formed another group from the remaining MBs. Similarly, in Waitakere City, where there are $1126 \mathrm{MBs}, 541 \mathrm{MBs}$ were valued in 1989, 871 in 1992, while the rest were only valued from 1995 onwards. In order to measure the change in land value ratios, we divided this TA into 3 groups. The first group contains $541 \mathrm{MBs}$ which have valuations available for all cycle years; the second group contains 330 MBs which have valuations available from 1992 onwards; the remaining MBs, which have valuations available from 1995, make up group 3. Suspicious MBs could then be tested based on the lv_mbta calculated within each of the three groups. ${ }^{13}$

Secondly, we plotted lv_mbta for suspicious MBs, identified according to the above rules, together with the aggregated land area in each cycle year in order to identify unreliable observations and adjust them accordingly. Land values in start or end cycle years that are extremely different from other cycle years were dropped from the time series and left

\footnotetext{
${ }^{12}$ See Table 3 in the Appendix for the list of these $116 \mathrm{MBs}$, as well as the Area Unit (AU) and TA to which they belong.

${ }^{13}$ See Figures 1 and 2 in the Appendix for the available land values in North Shore City and Waitakere City.
} 
as missing. ${ }^{14}$ Land values in the middle period that are significantly different from other cycle years were linearly interpolated using the data from neighbouring cycle years. For example, if we considered that the land value for MB x in 1994 in Auckland was suspicious, then we would linearly interpolate the lv_mbta in 1994 between 1991 and 1997 for that MB, then apply the interpolated $1994 \mathrm{lv} \_$mbta to $1994 \mathrm{lv}$ ta to get the interpolated $1994 \mathrm{lv} \_m b .{ }^{15}$ The rules we used to identify offending observations in the middle cycles are as follows:

- the lv_mbta follows an "up-down-up" trend and the "down" change exceeds $20 \%$ and at least one of the "up" changes exceeds $20 \%$, and the area of the corresponding years follows the same "up-down-up" pattern, and the changes in area are material; or

- the lv_mbta follows "down-up-down" trend and the "up" change exceeds $20 \%$ and at least one of the "down" changes exceeds $20 \%$, and the area of the corresponding years follows the same "down-up-down" pattern, and the changes in area are material; or

- the change of $1 \mathrm{v}$ _mbta is dramatic, (e.g. drop of more than $40 \%$ or increase of more than $80 \%$ ) and the total area remains broadly stable during the same period.

The changes resulted from the above process for each TA in the Greater Auckland are listed in Table 4 in the Appendix. This approach led us to clean 1.6\% of the observations across the seven TAs over all cycle years.

\section{$4 \quad$ Final Data}

Applying the interpolation method to the adjusted QVNZ dataset, we get a timeseries of land values in each MB from 1990 onwards for all 7 TAs in Greater Auckland. The final data point differs across TAs depending on their final available cycle year. Data extends to 2003 for Papakura and Franklin, to 2004 for Rodney and Waitakere, and to 2005 for North Shore, Auckland City and Manukau. For some TAs, the data begin earlier than 1990 (e.g. 1987 for Manukau City) but our concentration here is on the data from 1990 onwards.

\footnotetext{
${ }^{14}$ For example, if $1 \mathrm{v}$ mbta in the last cycle year is over $80 \%$ higher than the previous cycle year, where the land area covered by properties is approximately the same, we dropped the last observation and made the time-series stop at the second to last cycle year.

${ }^{15}$ Note the lv_mbta for the TA will not add exactly to 1 after the interpolation, and the $1 \mathrm{v}$ ta will also be fractionally different if we add up the interpolated lv_mb.
} 
To observe relative land price by $\mathrm{MB}$, we map the price for each $\mathrm{MB}$ relative to the price for Greater Auckland in each year. By relative price, we mean the ratio between the per hectare price for the MB and the per hectare price for all 7 TAs in Greater Auckland. The per hectare land price in a MB is calculated by using the land value in each MB divided by the total geographic land area defined by SNZ; and the per hectare land price for Greater Auckland is calculated by using the total land price in Greater Auckland divided by the total SNZ land area covered by all valued MBs in Greater Auckland. MBs with no valuation data are not included in the area calculation. The reason for using the SNZ area is that it is constant across time. By contrast, the land area recorded in the QVNZ valuation dataset varies, and sometimes exceeds the SNZ MB area. A possible reason for this is that the recorded land area includes a big property where only part of its land is within the MB. Since we have no way to adjust the QVNZ land areas, we chose to use the constant SNZ MB area instead.

Maps in Figure 3 in the Appendix show the relative land prices for 4 groups of TAs: group 1, Rodney District; group 2, Waitakere City and North Shore City; group 3, Auckland City, Manukau City and Papakura District; and group 4, Franklin District. These maps cover the years 1991 to 2003 and are presented at three yearly intervals (to save space); data and maps for every year from 1990 onwards are available. 


\section{Appendix}

\section{Table 1 QVNZ land types ${ }^{16}$}

\begin{tabular}{l} 
QVNZ Land Types \\
\hline \hline Arable Irrigated \\
Arable Non Irrigated \\
Arable Pre 1995 \\
Arable Total \\
Commercial - built on \\
Commercial / Industrial Vacant \\
Dairying Factory \\
Dairying Pre 1995 \\
Dairying Total \\
Dairying Town Supply \\
Forestry Exotic \\
Forestry Indigenous / Protected \\
Forestry Total \\
Forestry Total of planted forestry \\
Forestry Vacant \\
Horticulture Total \\
Industrial - built on \\
Lifestyle Improved \\
Lifestyle Total \\
Lifestyle Vacant \\
Mining Total \\
Other Total \\
Pastoral Fattening / Stud \\
Pastoral Grazing \\
Pastoral Run \\
Pastoral Total \\
Residential Built On \\
Residential Converted Flat \\
Residential Dwelling \\
Residential Flat / Own Your Own \\
Residential Home and Income \\
Residential Parents of Mixed Use \\
Residential Purpose Built Flat \\
Residential Vacant \\
Specialist Aquaculture \\
Specialist Deer \\
Specialist Horses \\
Specialist Other \\
Specialist Pigs \\
Specialist Poultry \\
Specialist Pre 1995 \\
Specialist Total \\
\hline
\end{tabular}

\footnotetext{
${ }^{16}$ Not all the land types listed here are included in our aggregated data. First, we dropped the sub-group totals since they repeat the values of each type within the sub-group. The dropped sub-groups totals are Dairying Total, Forestry Total, Lifestyle Total, Pastoral Total and Specialist Total. Second, we drop Arable irrigated, Arable Non-irrigated and Arable Pre 1995 but keep Arable Total because the three detailed types are not welldefined.
} 
Table 2 Cycle Years by TA

\begin{tabular}{|l|l|l|l|l|l|l|l|l|l|}
\hline TA ID & TA Name & \# of MBs & \multicolumn{7}{|c|}{ Cycle Years } \\
\hline \hline 4 & Rodney District & 563 & 1989 & 1992 & 1995 & 1998 & 2001 & 2004 & \\
\hline 5 & North Shore City & 1,424 & 1988 & 1990 & 1993 & 1996 & 1999 & 2002 & 2005 \\
\hline 6 & Waitakere City & 1,126 & 1989 & 1992 & 1995 & 1998 & 2001 & 2004 & \\
\hline 7 & Auckland City & 3,088 & 1990 & 1991 & 1994 & 1997 & 1999 & 2002 & 2005 \\
\hline 8 & Manukau City & 1,859 & 1987 & 1990 & 1993 & 1996 & 1999 & 2002 & 2005 \\
\hline 9 & Papakura District & 280 & 1988 & 1991 & 1994 & 1997 & 2000 & 2003 & \\
\hline 10 & Franklin District & 463 & 1989 & 1992 & 1995 & 1998 & 2001 & 2003 & \\
\hline & Total & $\mathbf{8 , 8 0 3}$ & & & & & & & \\
\hline
\end{tabular}


Table 3 MBs in Greater Auckland that do not have any valuation data

\begin{tabular}{|c|c|c|c|c|c|}
\hline mb01 & au01_desc & ta01_desc & mb01 & au01_desc & ta01_desc \\
\hline 496102 & Abbotts Park & Auckland City & 835700 & Waiuku & Franklin District \\
\hline 432500 & Auckland Central West & Auckland City & 836703 & Waiuku & Franklin District \\
\hline 434901 & Auckland Central West & Auckland City & 837900 & Waiuku & Franklin District \\
\hline 435202 & Auckland Central West & Auckland City & 720500 & Ambury & Manukau City \\
\hline 435300 & Auckland Central West & Auckland City & 719000 & Beachlands-Maraetai & Manukau City \\
\hline 544301 & Eden Terrace & Auckland City & 717000 & Clevedon & Manukau City \\
\hline 413200 & Freemans Bay & Auckland City & 684701 & Edgewater & Manukau City \\
\hline 415200 & Freemans Bay & Auckland City & 729700 & Favona & Manukau City \\
\hline 417200 & Freemans Bay & Auckland City & 750100 & Favona & Manukau City \\
\hline 417400 & Freemans Bay & Auckland City & 608342 & Inlet-Manukau Harbour & Manukau City \\
\hline 476500 & Glen Innes West & Auckland City & 608344 & Inlet-Manukau Harbour & Manukau City \\
\hline 440104 & Inlet-Hobson Bay & Auckland City & 608350 & Inlet-Manukau Harbour & Manukau City \\
\hline 516900 & Islands-Motutapu, Rangitoto, Rak & Auckland City & 608352 & Inlet-Manukau Harbour & Manukau City \\
\hline 517101 & Islands-Motutapu, Rangitoto, Rak & Auckland City & 608354 & Inlet-Manukau Harbour & Manukau City \\
\hline 517200 & Islands-Motutapu, Rangitoto, Rak & Auckland City & 634336 & Inlets-Tamaki & Manukau City \\
\hline 517300 & Islands-Motutapu, Rangitoto, Rak & Auckland City & 634340 & Inlets-Tamaki & Manukau City \\
\hline 517600 & Islands-Motutapu, Rangitoto, Rak & Auckland City & 634344 & Inlets-Tamaki & Manukau City \\
\hline 529100 & Kingsland & Auckland City & 634366 & Inlets-Tamaki & Manukau City \\
\hline 584401 & Lynfield North & Auckland City & 634372 & Inlets-Tamaki & Manukau City \\
\hline 439400 & Mokohinau Island & Auckland City & 726600 & Mangere South & Manukau City \\
\hline 546200 & Mt Eden North & Auckland City & 726700 & Mangere South & Manukau City \\
\hline 637802 & Mt Wellington South & Auckland City & 727300 & Mangere South & Manukau City \\
\hline 412900 & Newton & Auckland City & 727800 & Mangere South & Manukau City \\
\hline 623000 & One Tree Hill Central & Auckland City & 749300 & Mangere Station & Manukau City \\
\hline 623300 & One Tree Hill Central & Auckland City & 749400 & Mangere Station & Manukau City \\
\hline 455000 & Orakei North & Auckland City & 786400 & Middlemore & Manukau City \\
\hline 496400 & Orakei North & Auckland City & 786500 & Middlemore & Manukau City \\
\hline 496500 & Orakei North & Auckland City & 679812 & Pigeon Mountain North & Manukau City \\
\hline 788102 & Otahuhu East & Auckland City & 760142 & Redoubt South & Manukau City \\
\hline 790300 & Otahuhu East & Auckland City & 760200 & Redoubt South & Manukau City \\
\hline 786300 & Otahuhu West & Auckland City & 760801 & Redoubt South & Manukau City \\
\hline 520300 & Owairaka East & Auckland City & 717903 & Shelly Park & Manukau City \\
\hline 522703 & Owairaka East & Auckland City & 716800 & Turanga & Manukau City \\
\hline 457200 & Parnell East & Auckland City & 717100 & Turanga & Manukau City \\
\hline 457300 & Parnell East & Auckland City & 772902 & Wattle Farm & Manukau City \\
\hline 457500 & Parnell East & Auckland City & 357200 & Birkenhead East & North Shore City \\
\hline 622100 & Penrose & Auckland City & 351402 & Chelsea & North Shore City \\
\hline 391601 & Point Chevalier West & Auckland City & 352800 & Chelsea & North Shore City \\
\hline 393702 & Point Chevalier West & Auckland City & 185004 & Glendhu & North Shore City \\
\hline 428500 & Ponsonby West & Auckland City & 331000 & Mt Victoria & North Shore City \\
\hline 390300 & Rosebank & Auckland City & 179501 & Paremoremo East & North Shore City \\
\hline 390402 & Rosebank & Auckland City & 366601 & Tuff Crater & North Shore City \\
\hline 536100 & Sandringham North & Auckland City & 808602 & Rosehill & Papakura District \\
\hline 423800 & St Marys & Auckland City & 142000 & Algies Bay-Mahurangi & Rodney District \\
\hline 291102 & Crum Park & Waitakere City & 175300 & Army Bay & Rodney District \\
\hline 253502 & Edmonton & Waitakere City & 138809 & Cape Rodney & Rodney District \\
\hline 222000 & Hobsonville & Waitakere City & 147314 & Cape Rodney & Rodney District \\
\hline 222100 & Hobsonville & Waitakere City & 147316 & Cape Rodney & Rodney District \\
\hline 222200 & Hobsonville & Waitakere City & 209200 & Helensville & Rodney District \\
\hline 222300 & Hobsonville & Waitakere City & 209902 & Helensville & Rodney District \\
\hline 222400 & Hobsonville & Waitakere City & 213300 & Inlet-Kaipara River & Rodney District \\
\hline 222600 & Hobsonville & Waitakere City & 172000 & Orewa & Rodney District \\
\hline 222700 & Hobsonville & Waitakere City & 210701 & Parakai & Rodney District \\
\hline 303300 & Karekare & Waitakere City & 172807 & Red Beach & Rodney District \\
\hline 282200 & Otimai & Waitakere City & 210302 & South Head & Rodney District \\
\hline 237402 & Swanson & Waitakere City & 170700 & Waiwera & Rodney District \\
\hline 237502 & Swanson & Waitakere City & & & \\
\hline 301800 & Waima & Waitakere City & & & \\
\hline 253900 & Wakeling & Waitakere City & & & \\
\hline 223500 & Whenuapai West & Waitakere City & & & \\
\hline
\end{tabular}


Table 4 MBs with Cleaned Data, and Corresponding Adjustments

\section{North Shore City}

\begin{tabular}{|l|l|l|}
\hline MB No. & Problem Cycle(s) & Adjustment(s) \\
\hline 162300 & 1999 & Interpolated between 1996 and 2002 \\
\hline 181000 & 2002 & Interpolated between 1999 and 2005 \\
\hline 183904 & 1990 & Drop \\
\hline 184600 & 1990 & Drop \\
\hline 184703 & 1990 & Drop \\
\hline 186102 & 1990 & Drop \\
\hline 200000 & 1999 & Interpolated between 1996 and 2002 \\
\hline 351600 & 1999 & Interpolated between 1996 and 2002 \\
\hline
\end{tabular}

Rodney District

\begin{tabular}{|l|l|l|}
\hline MB No. & Problem Cycle(s) & Adjustment(s) \\
\hline 139107 & 1992,1995 & Interpolated between 1989 and 1998 \\
\hline 139700 & 2001 & Interpolated between 1998 and 2004 \\
\hline 145300 & 2001 & Interpolated between 1998 and 2004 \\
\hline 145900 & 2001 & Interpolated between 1998 and 2004 \\
\hline 175104 & 1989 & Drop \\
\hline 208202 & 1989,1992 & Drop \\
\hline 213000 & 1998 & Interpolated between 1995 and 2001 \\
\hline 214300 & 1998 & Interpolated between 1995 and 2001 \\
\hline 217000 & 1995 & Interpolated between 1992 and 1998 \\
\hline 218800 & $1989-1995$ & Drop \\
\hline 226501 & 2001 & Interpolated between 1998 and 2004 \\
\hline
\end{tabular}

Waitakere City

\begin{tabular}{|l|l|l|}
\hline MB No. & Problem Cycle(s) & Adjustment(s) \\
\hline 181600 & 1989 & Drop \\
\hline 221600 & 2004 & Drop \\
\hline 223700 & 1995 & Interpolate between 1992 and 1998 \\
\hline 224106 & 1992,1995 & Interpolate between 1989 and 1998 \\
\hline 224125 & 1989,1992 & Drop \\
\hline 229702 & 1989,1992 & Drop \\
\hline 230301 & 1992 & Interpolate between 1989 and 1995 \\
\hline 230500 & 1989,1992 & Drop \\
\hline 230702 & 1989 & Drop \\
\hline 237203 & 1992 & Drop \\
\hline 237300 & 1989,1992 & Drop \\
\hline 238200 & 1989 & Drop \\
\hline 238400 & 1989 & Drop \\
\hline 242501 & 1998 & Interpolate between 1995 and 2001 \\
\hline 242700 & 1998 & Interpolate between 1995 and 2001 \\
\hline 251100 & 1989,1992 & Drop \\
\hline 252000 & 1992 & Interpolate between 1989 and 1995 \\
\hline 266000 & All & Blank all the time \\
\hline 278003 & 1989 & Drop \\
\hline 282008 & 1998 & Interpolate between 1995 and 2001 \\
\hline 289200 & 1998 & Interpolate between 1995 and 2001 \\
\hline 290800 & 1995 & Interpolate between 1992 and 1998 \\
\hline
\end{tabular}

Papakura District

\begin{tabular}{|l|l|l|}
\hline MB No. & Problem Cycle(s) & Adjustment(s) \\
\hline 807400 & 1997 & Interpolated between 1994 and 2000 \\
\hline
\end{tabular}




\section{Auckland City}

\begin{tabular}{|c|c|c|}
\hline MB No. & Problem Cycle(s) & Adjustment(s) \\
\hline 383600 & $1990-2002$ & Drop \\
\hline 391602 & $1990 \& 2005$ & Drop \\
\hline 397600 & $1990-1994$ & Drop \\
\hline 413000 & $1990-2002$ & Drop \\
\hline 413300 & 1999 & Interpolate between 1994 and 2002 \\
\hline 417700 & 1990-1994 & Drop \\
\hline 426100 & $1990-2005$ & Blank all the time \\
\hline 429200 & $1990-2005$ & Blank all the time \\
\hline 429500 & 1990 & Drop \\
\hline 432000 & 1990-1994 & Drop \\
\hline 433100 & $1990-2002$ & Drop \\
\hline 436700 & 1990-1994 & Drop \\
\hline 437900 & $1990-2002$ & Drop \\
\hline 438102 & 1990-1999 & Drop \\
\hline 438202 & 1990-1994 & Drop \\
\hline 438500 & 1990-1994 & Drop \\
\hline 440400 & 1990-1999 & Drop \\
\hline 441200 & 1990-1994 & Drop \\
\hline 442100 & $1990-2005$ & Blank all the time \\
\hline 443600 & 1990-2002 & Drop \\
\hline 451900 & 1990-1994 & Drop \\
\hline 454900 & 2002 & Interpolate between 1999 and 2005 \\
\hline 457600 & 1994 & Interpolate between 1991 and 1999 \\
\hline 463901 & $1990-2005$ & Blank all the time \\
\hline 466700 & 1994 & Interpolate between 1991 and 1999 \\
\hline 468300 & 1994 & Interpolate between 1991 and 1999 \\
\hline 482400 & 1994 & Interpolate between 1991 and 1999 \\
\hline 485500 & $1999 \& 2002$ & Interpolate between 1994 and 2005 \\
\hline 489500 & $1990-2002$ & Drop \\
\hline 494902 & 1990-1994 & Drop \\
\hline 497000 & $1990-2002$ & Drop \\
\hline 497900 & 1999 & Interpolate between 1994 and 2002 \\
\hline 498100 & 1994 & Interpolate between 1991 and 1999 \\
\hline 499800 & 1994 & Interpolate between 1991 and 1999 \\
\hline 503300 & $1990-2005$ & Blank all the time \\
\hline 511400 & 1994 & Interpolate between 1991 and 1999 \\
\hline 512200 & $1990 \& 1994$ & Drop 1990; Interpolate 1994 between 1991 and 1999 \\
\hline 514400 & $1990 \& 1994$ & Drop 1990; Interpolate 1994 between 1991 and 1999 \\
\hline 514600 & 1994 & Interpolate between 1991 and 1999 \\
\hline 520000 & 2005 & Drop \\
\hline 530000 & 2005 & Drop \\
\hline 530900 & 2005 & Drop \\
\hline 534200 & 2002 & Interpolate between 1999 and 2005 \\
\hline 536200 & $1990 \& 1991$ & Drop \\
\hline 543000 & $1990-2002$ & Drop \\
\hline 544000 & 2005 & Drop \\
\hline 548200 & 2005 & Drop \\
\hline 553700 & 2002 & Interpolate between 1999 and 2005 \\
\hline 561200 & $1999 \& 2005$ & Drop 2005; Interpolate 1999 between 1994 and 2002 \\
\hline 563902 & $1990-2002$ & Drop \\
\hline 571700 & 1990-1994 & Drop \\
\hline 577000 & 2005 & Drop \\
\hline 579100 & 1999 & Interpolate between 1994 and 2002 \\
\hline 581700 & 2002 & Interpolate between 1999 and 2005 \\
\hline 589204 & $1990 \& 2005$ & Drop \\
\hline 589205 & $1990-1999$ & Drop \\
\hline 598800 & 1990-2002 & Drop \\
\hline 600800 & 1990 & Drop \\
\hline 601000 & 1990 & Drop \\
\hline
\end{tabular}




\begin{tabular}{|l|l|l|}
\hline MB No. & Problem Cycle(s) & Adjustment(s) \\
\hline 601600 & $1990-2002$ & Drop \\
\hline 601800 & 1990 & Drop \\
\hline 602401 & 2002 & Interpolate between 1999 and 2005 \\
\hline 607500 & 1990 & Drop \\
\hline 607800 & 1990 & Drop \\
\hline 612200 & 1990 & Drop \\
\hline 616300 & 2005 & Drop \\
\hline 616600 & 1994 & Interpolate between 1991 and 1999 \\
\hline 616900 & $1990-2002$ & Drop \\
\hline 622500 & $1990-2002$ & Drop \\
\hline 624000 & 1994 & Interpolate between 1991 and 1999 \\
\hline 625500 & $1990 \& 2005$ & Drop \\
\hline 629300 & 1990 & Drop \\
\hline 631100 & 1990 & Drop \\
\hline 637500 & $1990-1999$ & Drop \\
\hline 637801 & 1990 & Drop \\
\hline 640002 & $1999 \& 2002$ & Interpolate between 1994 and 2005 \\
\hline 642500 & 2002 & Interpolate between 1999 and 2005 \\
\hline 644101 & $1990-2005$ & Blank all the time \\
\hline 785200 & 1999 & Interpolate between 1994 and 2002 \\
\hline 787200 & 2005 & Drop \\
\hline 788300 & 2005 & Drop \\
\hline 789100 & 2002 & Interpolate between 1999 and 2005 \\
\hline & & \\
\hline
\end{tabular}

\section{Manukau City}

\begin{tabular}{|l|l|l|}
\hline MB No. & Problem Cycle(s) & Adjustment(s) \\
\hline 648400 & 1990 & Interpolate between 1987 and 1993 \\
\hline 678900 & 2002 & Interpolate between 1999 and 2005 \\
\hline 711136 & $1990 \& 1996$ & Drop 1990; Interpolate 1996 between 1993 and 1999 \\
\hline 711141 & $1990 \& 1993$ & Drop \\
\hline 711146 & 1987 to 1993 & Drop \\
\hline 711149 & $1987 \& 1990$ & Drop \\
\hline 711300 & 2002 & Interpolate between 1999 and 2005 \\
\hline 711408 & $1987 \& 1990$ & Drop \\
\hline 711703 & 1987 & Drop \\
\hline 712020 & 1987 to 1993 & Drop \\
\hline 712024 & 1987 to 1996 & Drop \\
\hline 712201 & 2002 & Interpolate between 1999 and 2005 \\
\hline 720800 & $2002 \& 2005$ & Drop \\
\hline 730800 & 1990 to 1996 & Drop \\
\hline 731600 & $1987 \& 1990$ & Drop \\
\hline 749800 & 2002 & Interpolate between 1999 and 2005 \\
\hline 749900 & 1999 & Interpolate between 1996 and 2002 \\
\hline 751600 & 1993 & Interpolate between 1990 and 1996 \\
\hline 774431 & 1987 & Drop \\
\hline 780404 & 1987 & Drop \\
\hline 780700 & 1996 & Interpolate between 1993 and 1999 \\
\hline
\end{tabular}

\section{Franklin District}

\begin{tabular}{|l|l|l|}
\hline MB No. & Problem Cycle(s) & Adjustment(s) \\
\hline 815900 & 1995 & Interpolate between 1992 and 1998 \\
\hline 833900 & 1998 & Interpolate between 1995 and 2001 \\
\hline 841000 & 1998 & Interpolate between 1995 and 2001 \\
\hline 843300 & 1998 & Interpolate between 1995 and 2001 \\
\hline 844600 & 1998 & Interpolate between 1995 and 2001 \\
\hline 844700 & 1998 & Interpolate between 1995 and 2001 \\
\hline 846200 & 1998 & Interpolate between 1995 and 2001 \\
\hline 846300 & 1998 & Interpolate between 1995 and 2001 \\
\hline
\end{tabular}


Figure 1 Relative land price in North Shore City in $1988^{17}$

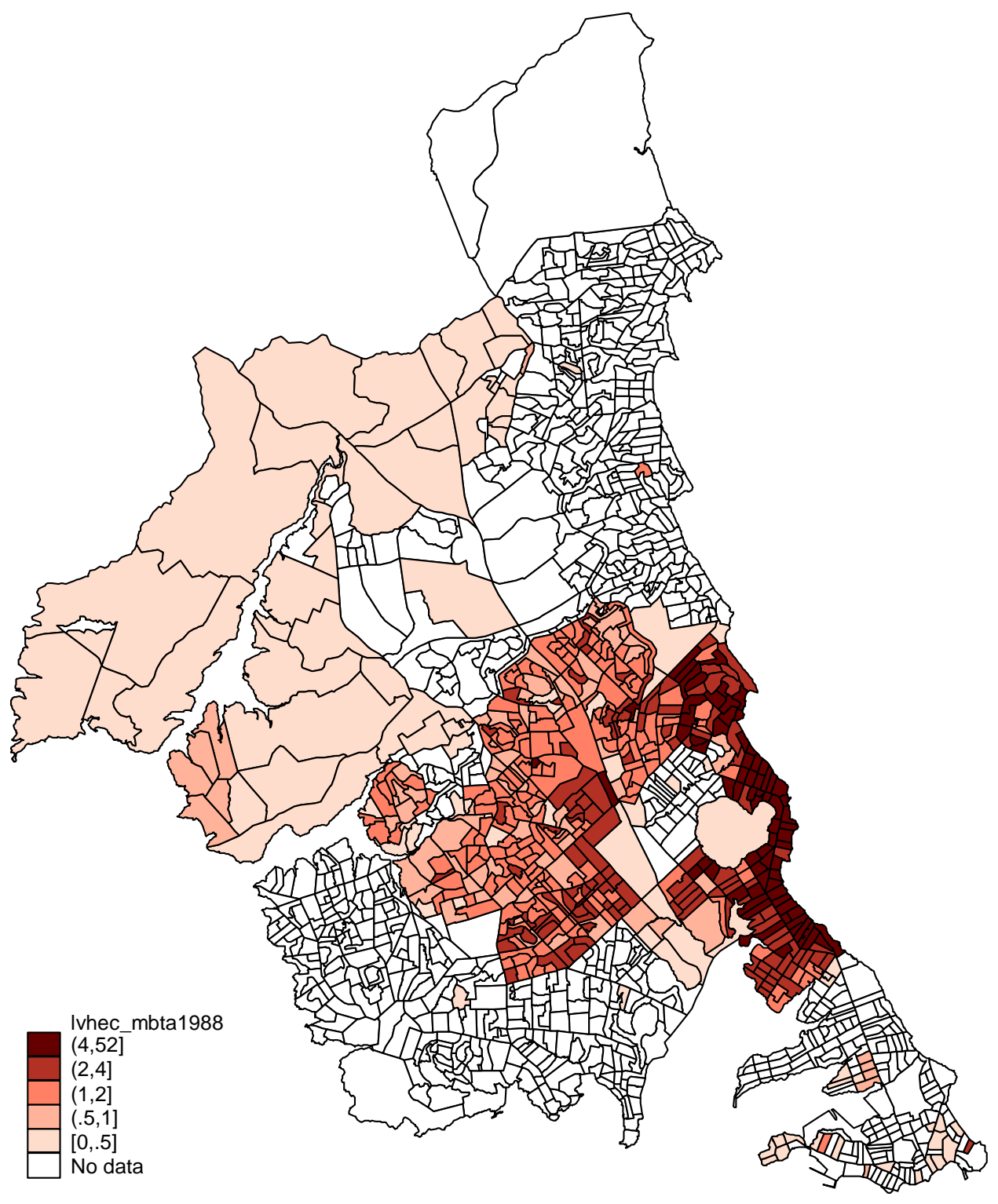

17 lvhec_mbta=lvhec_mb/lvhec_ta, where lvhec_mb=lv_mb/areaSNZ_mb, and lvhec_ta=lv_ta/areaSNZ_ta. Because $1988 \mathrm{QV}$ valuation only covered about half of the MBs, lvhec_ta in 1988 only counted the area from those MBs included in 1988 valuation data. The same is true for the Waitakere City in 1989 and 1992. 
Figure 2 Relative land price in Waitakere City in the first 2 cycle years

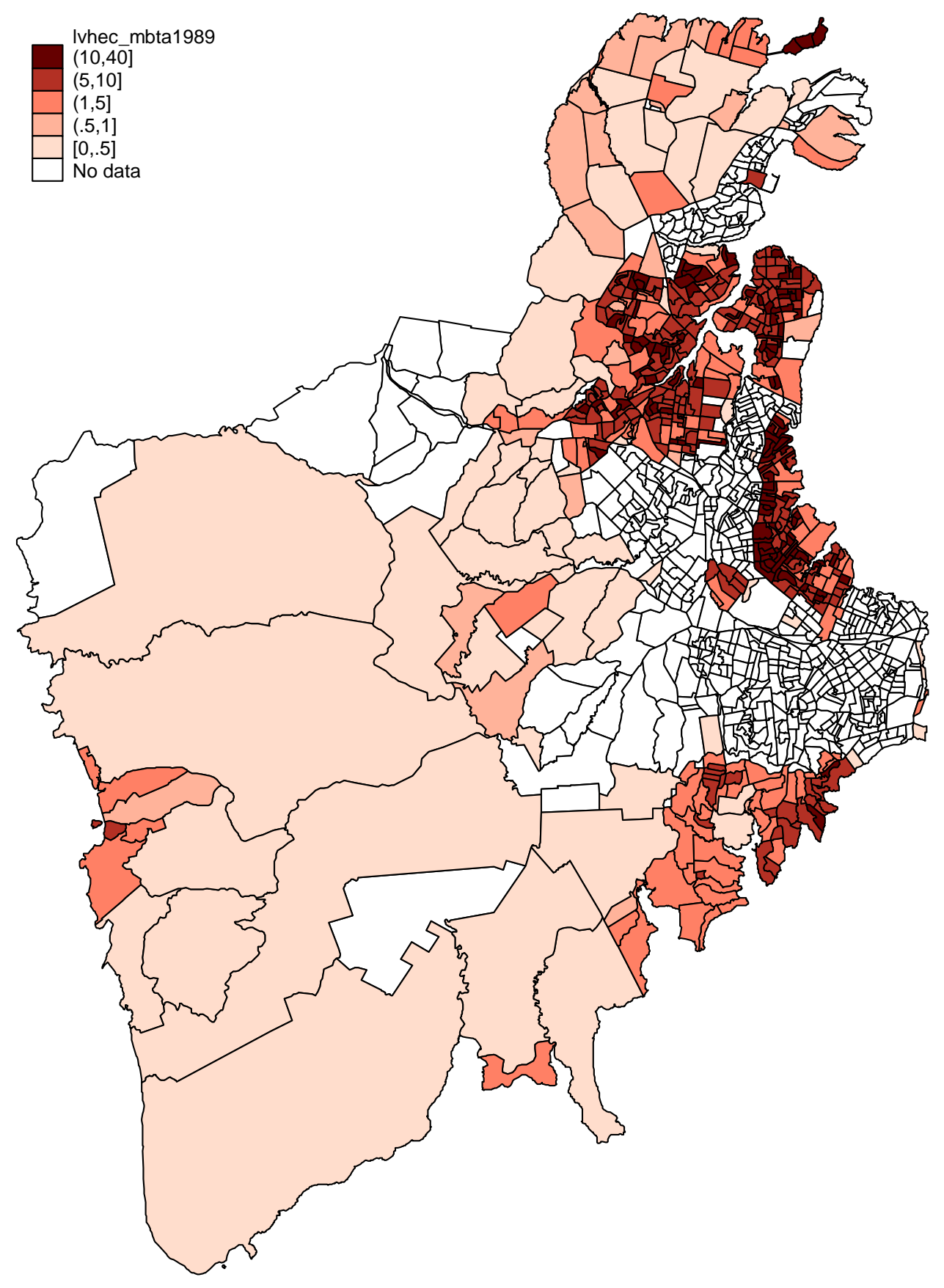




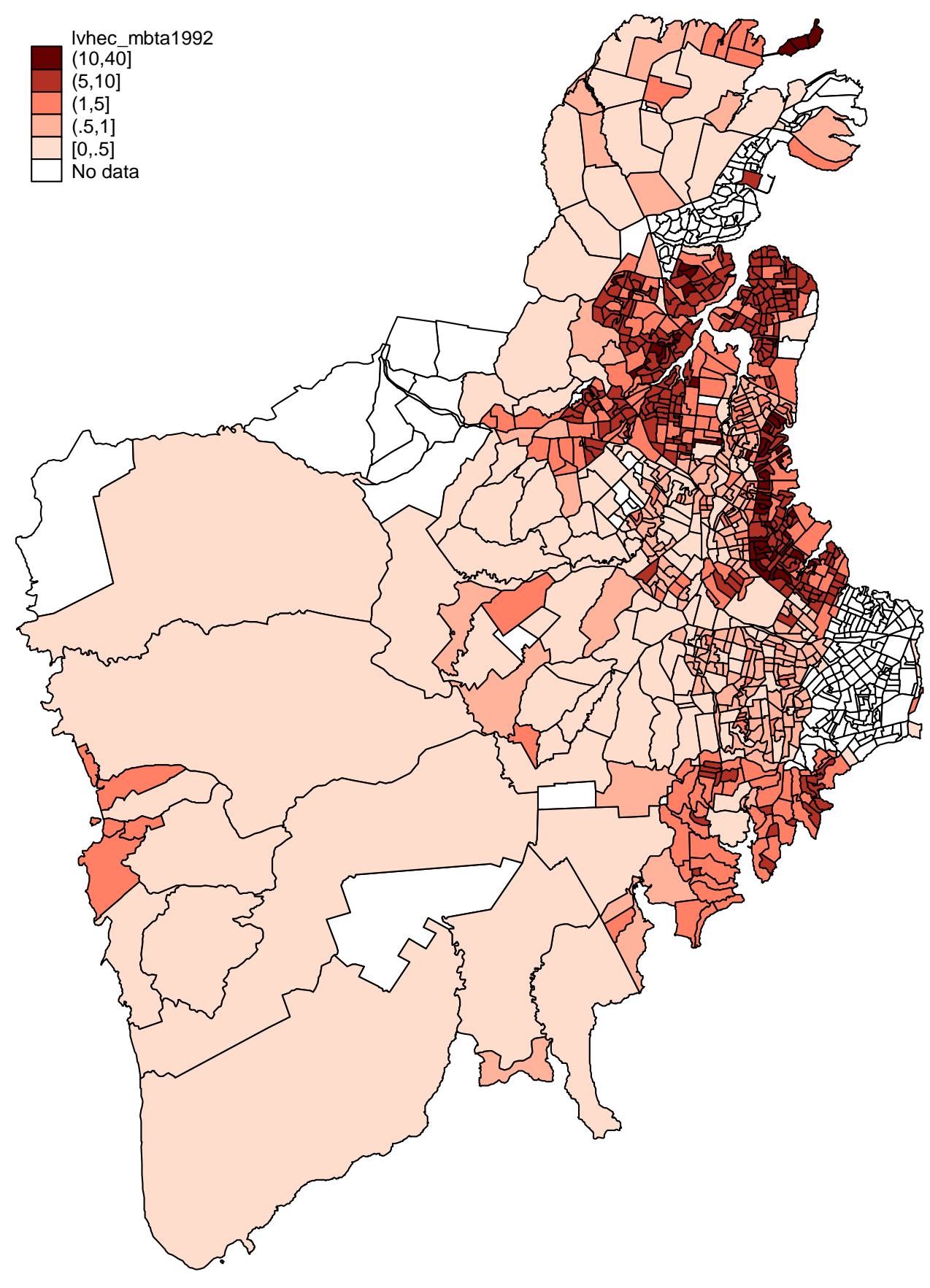


Figure 3 Relative Land Price by MB and year in Greater Auckland

1991

\section{Rodney District}

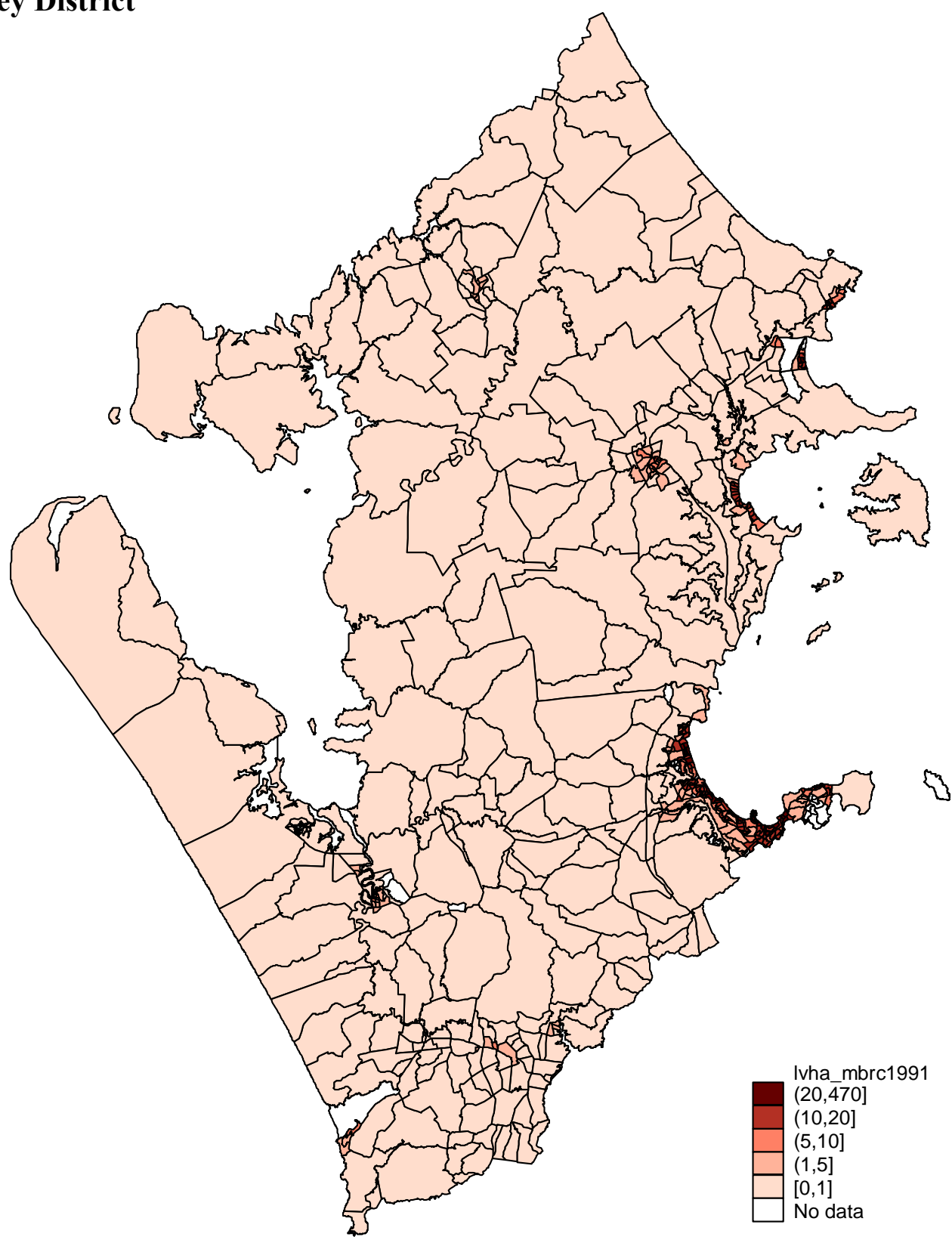


Waitakere City and North Shore City

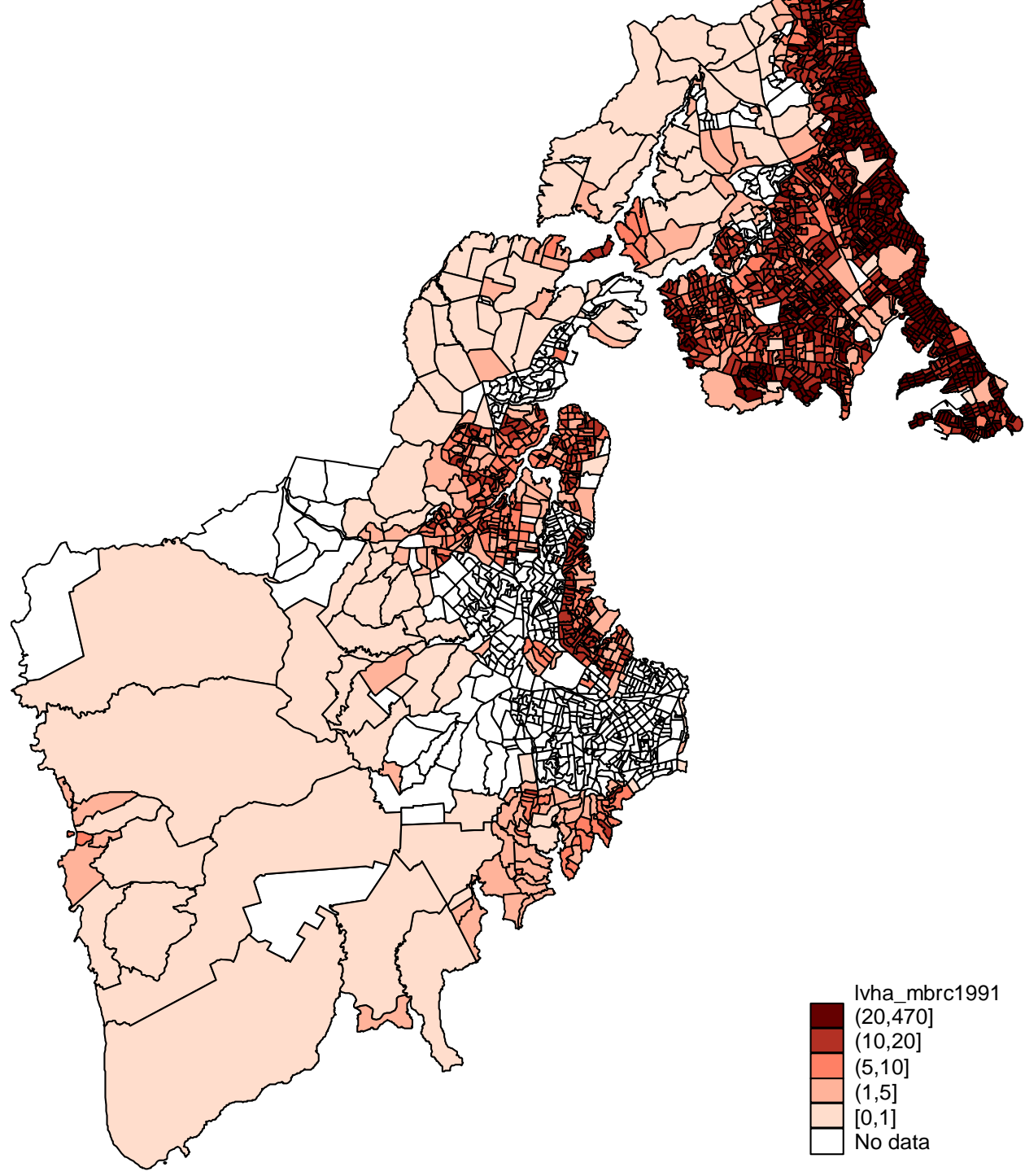




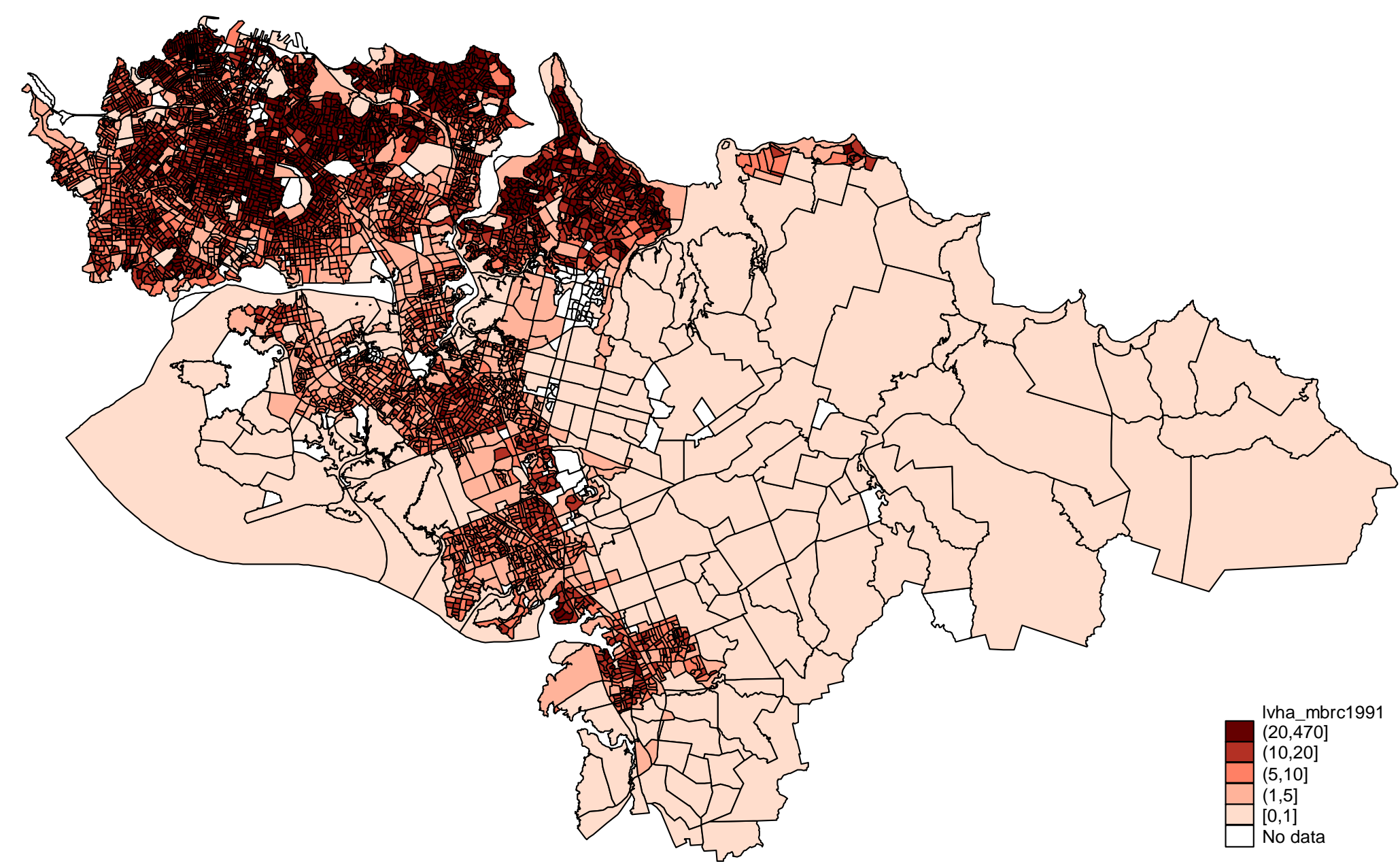




\section{Franklin District}

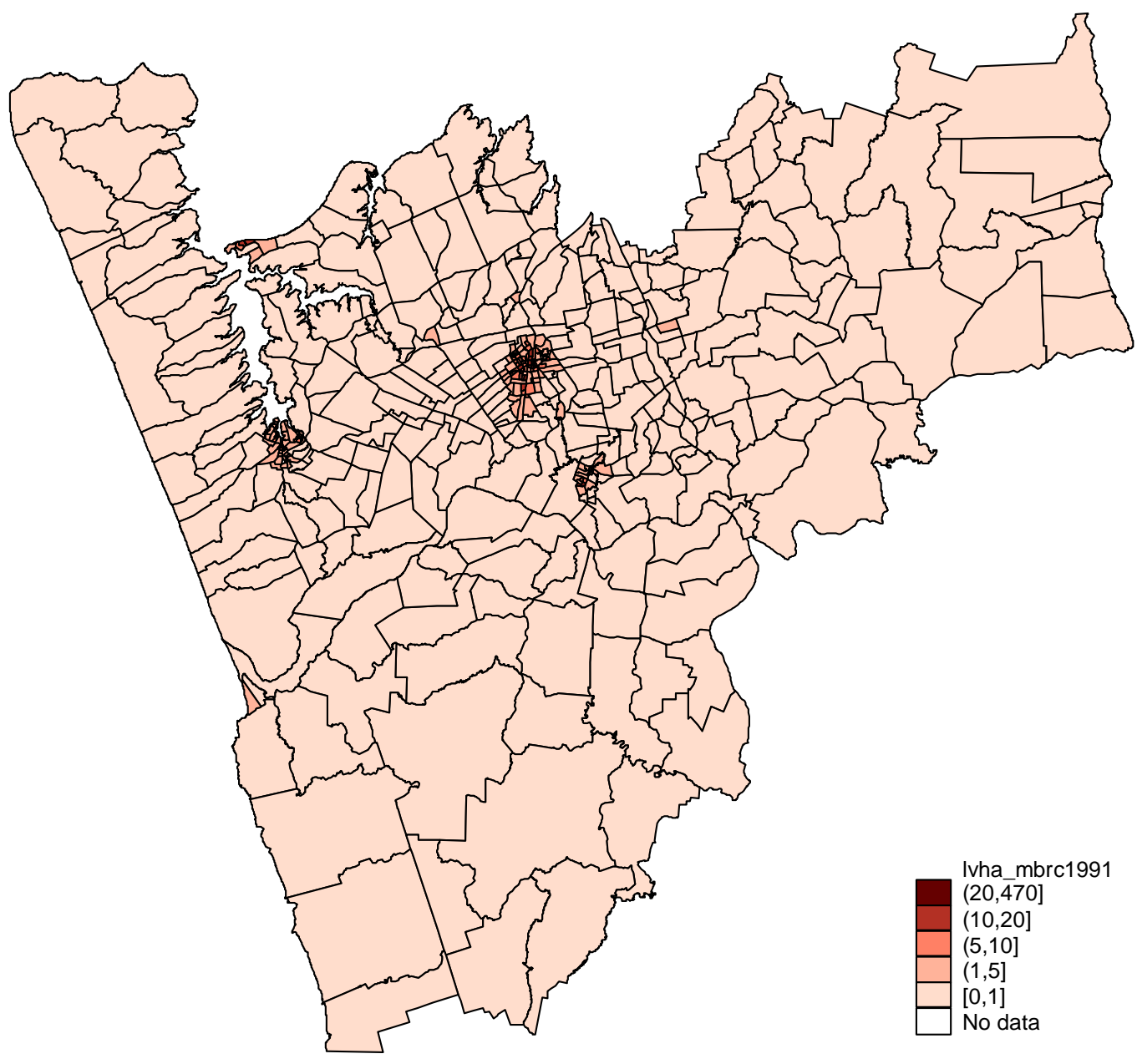




\section{Rodney District}

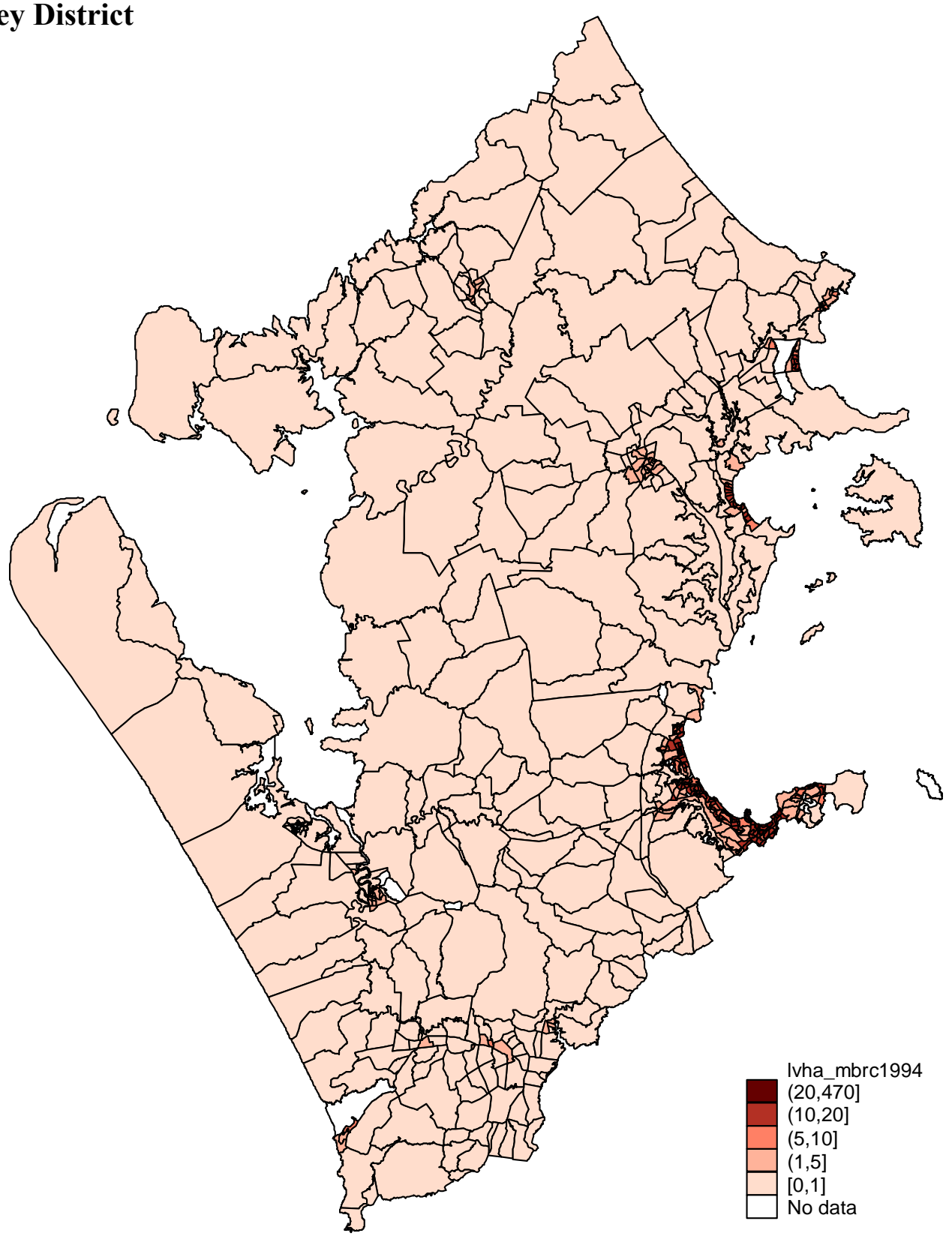


Waitakere City and North Shore City

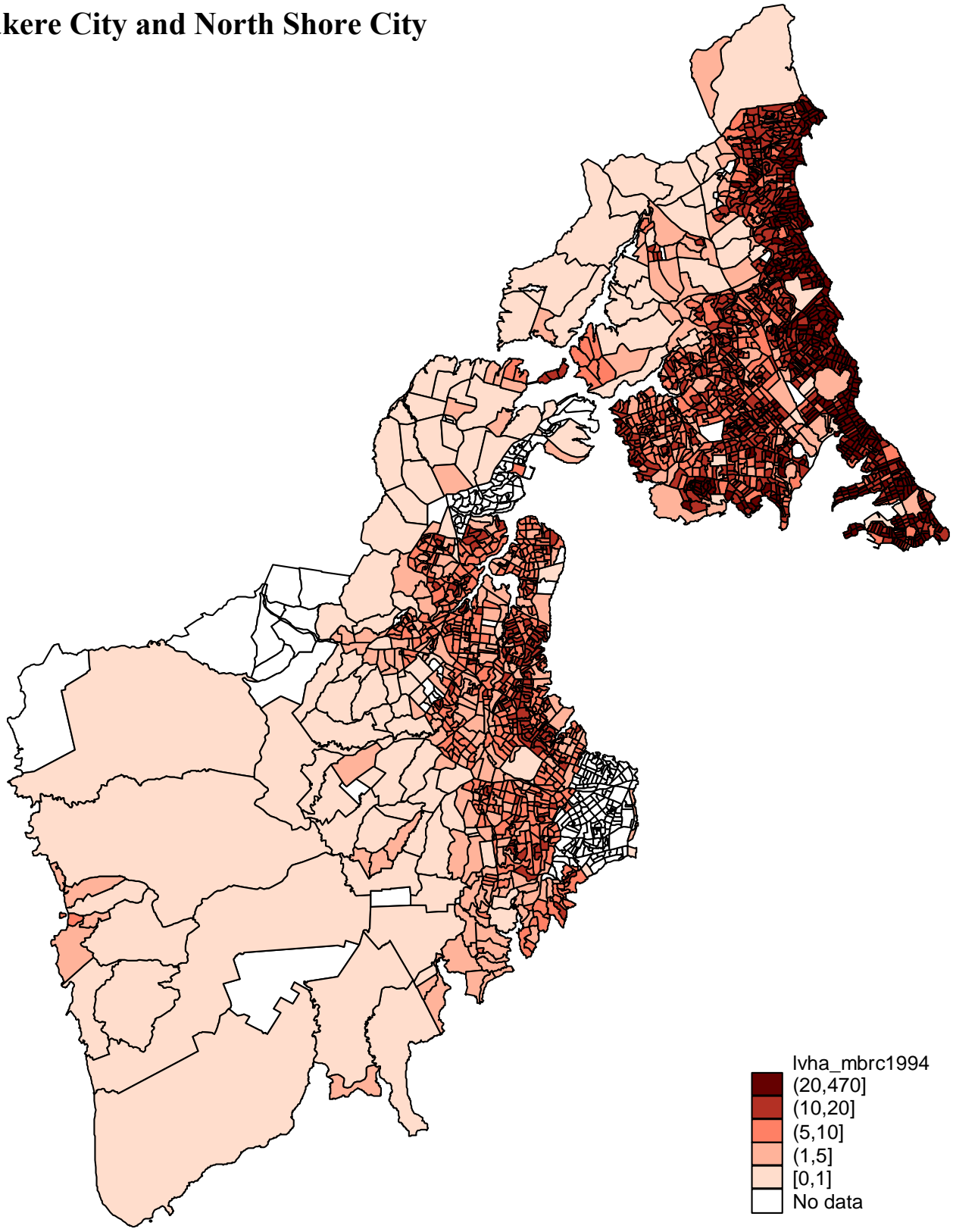


Auckland City, Manukau City and Papakura District

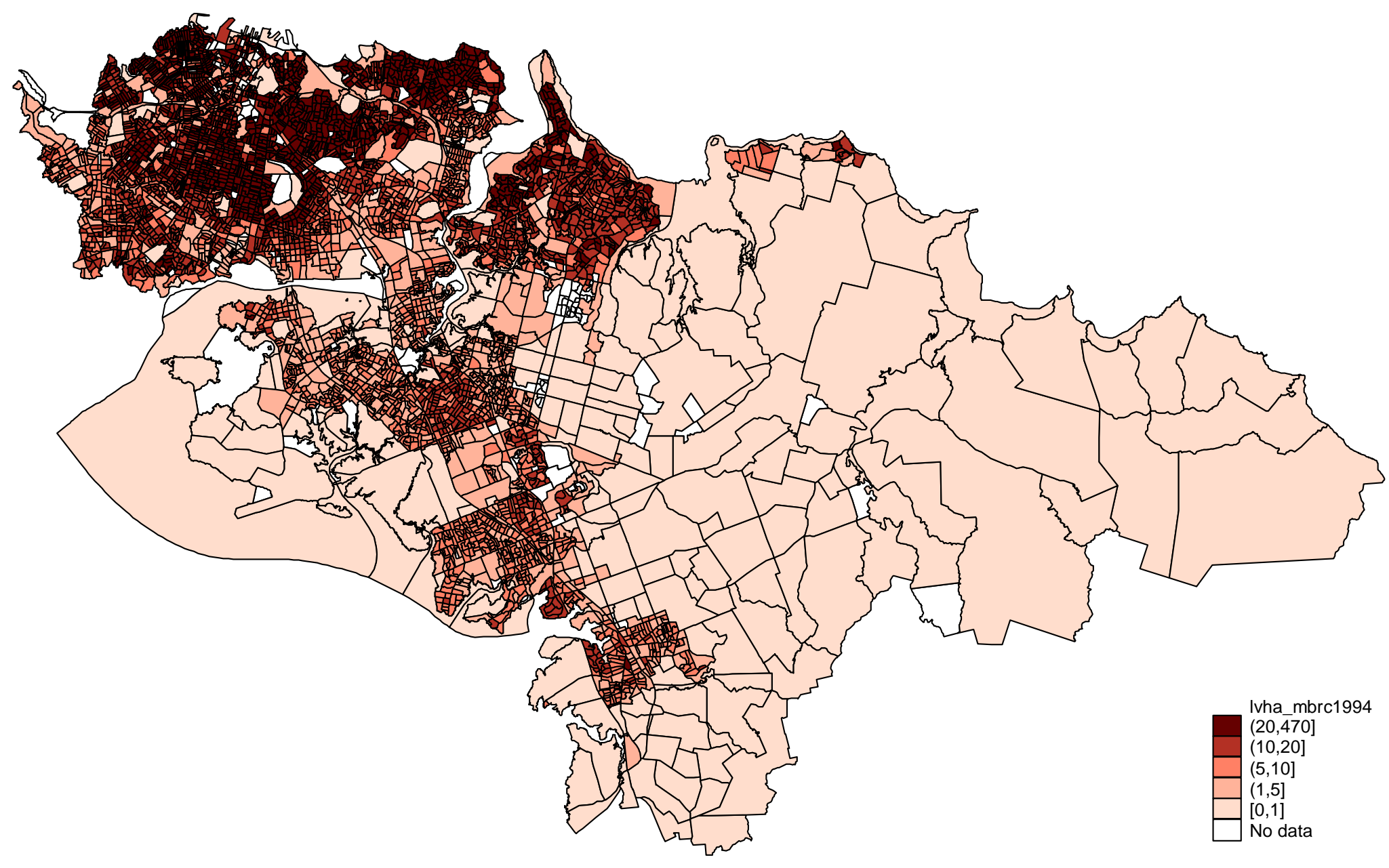

心 


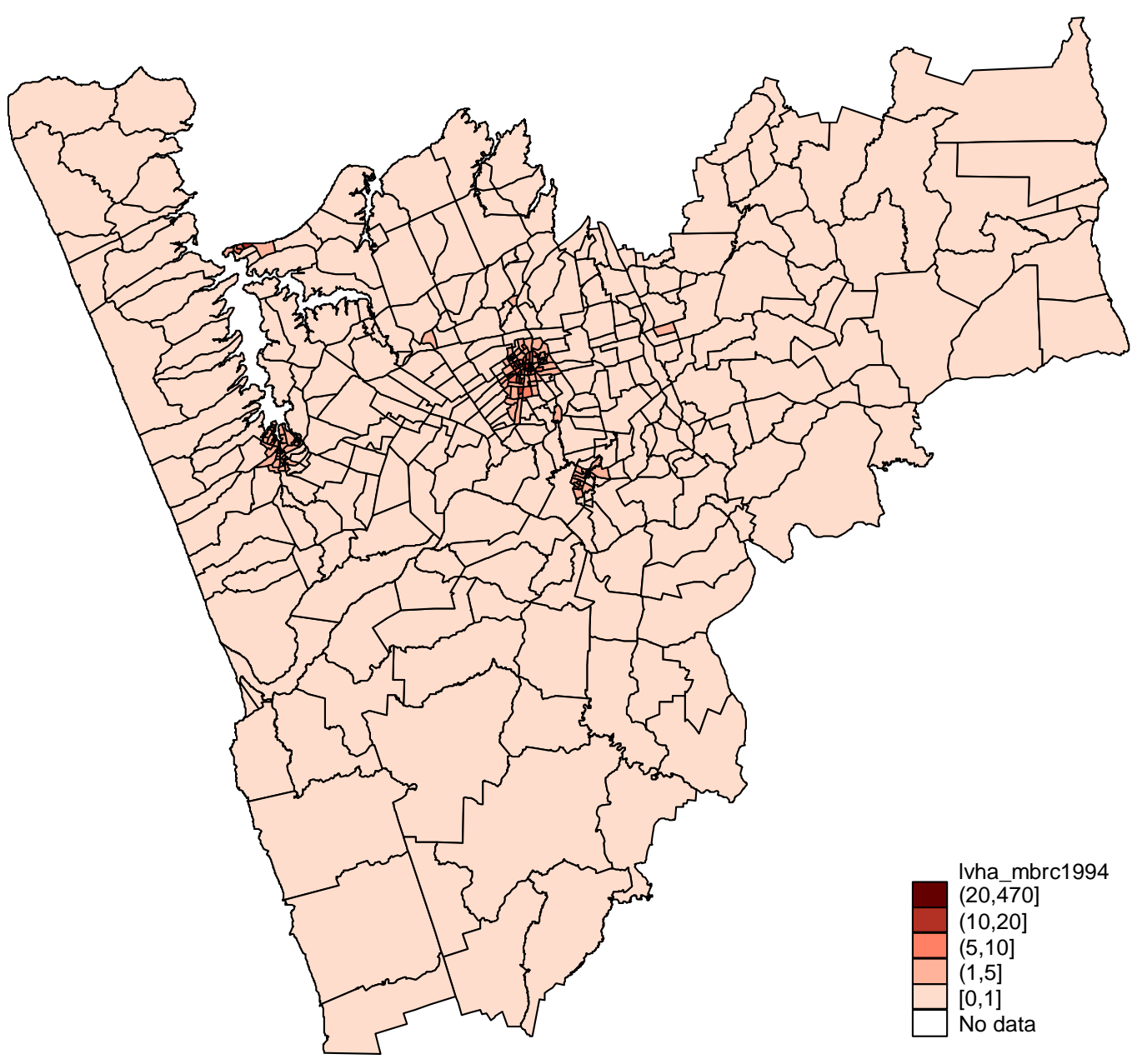




\section{Rodney District}

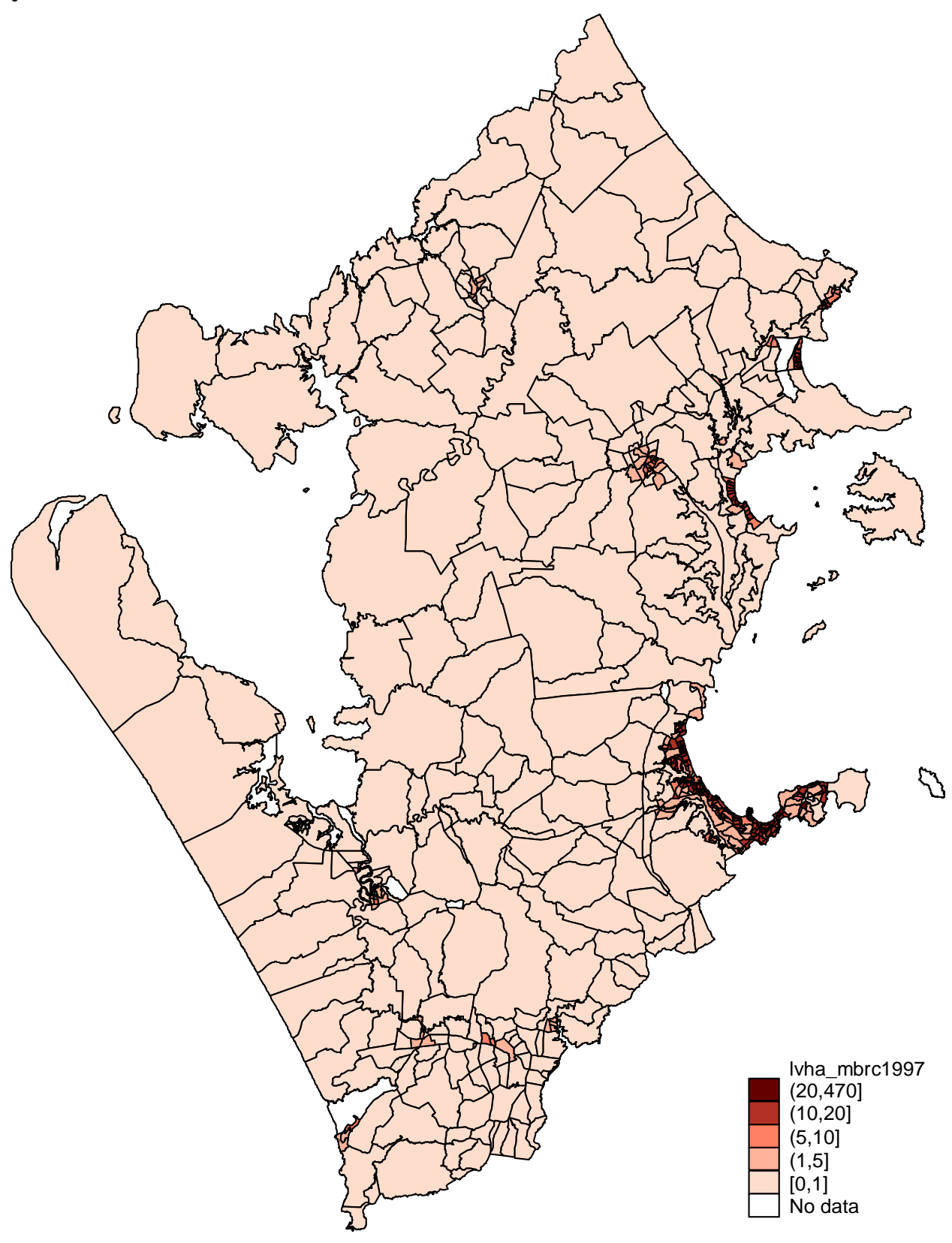


Waitakere City and North Shore City

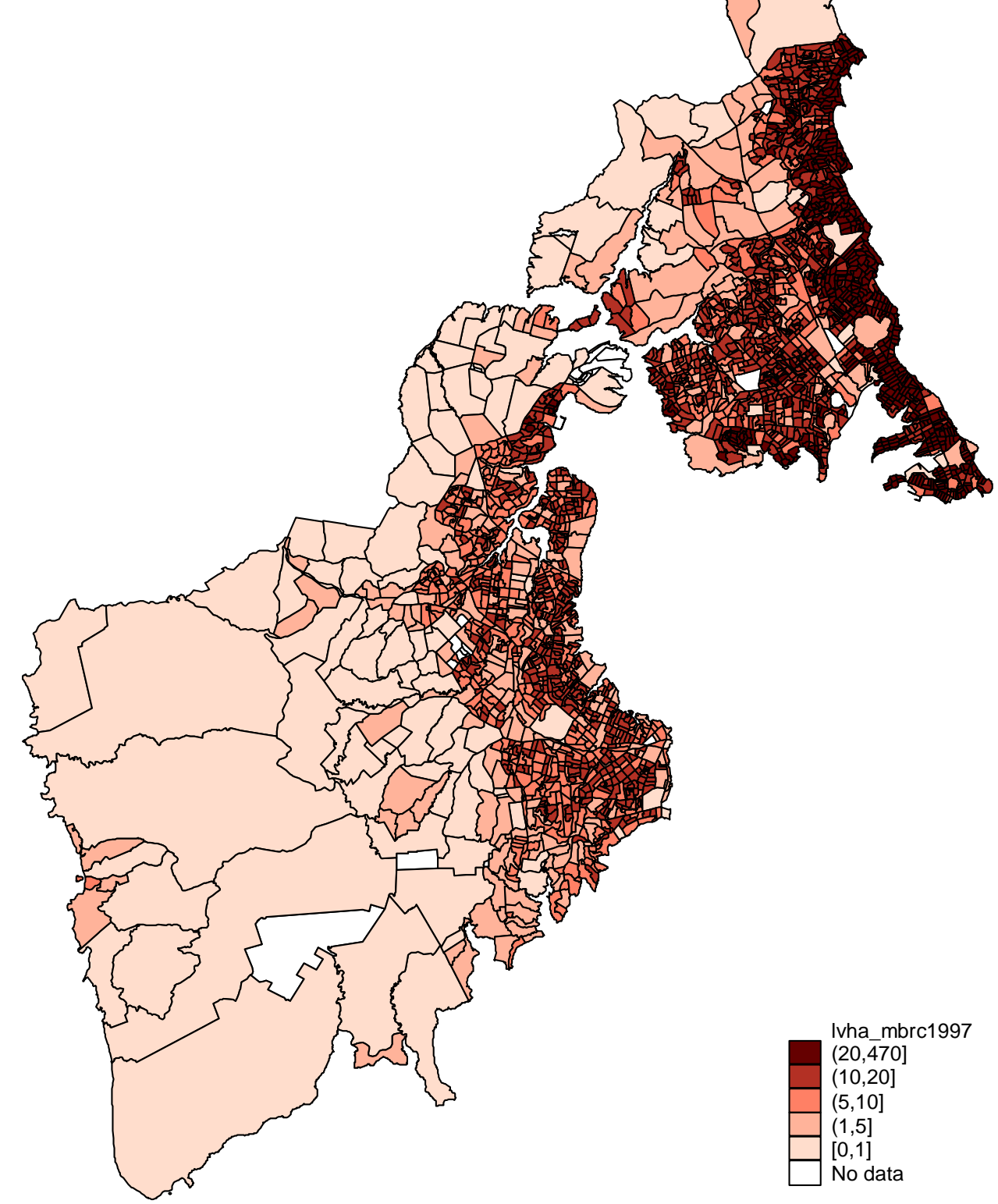


Auckland City, Manukau City and Papakura District

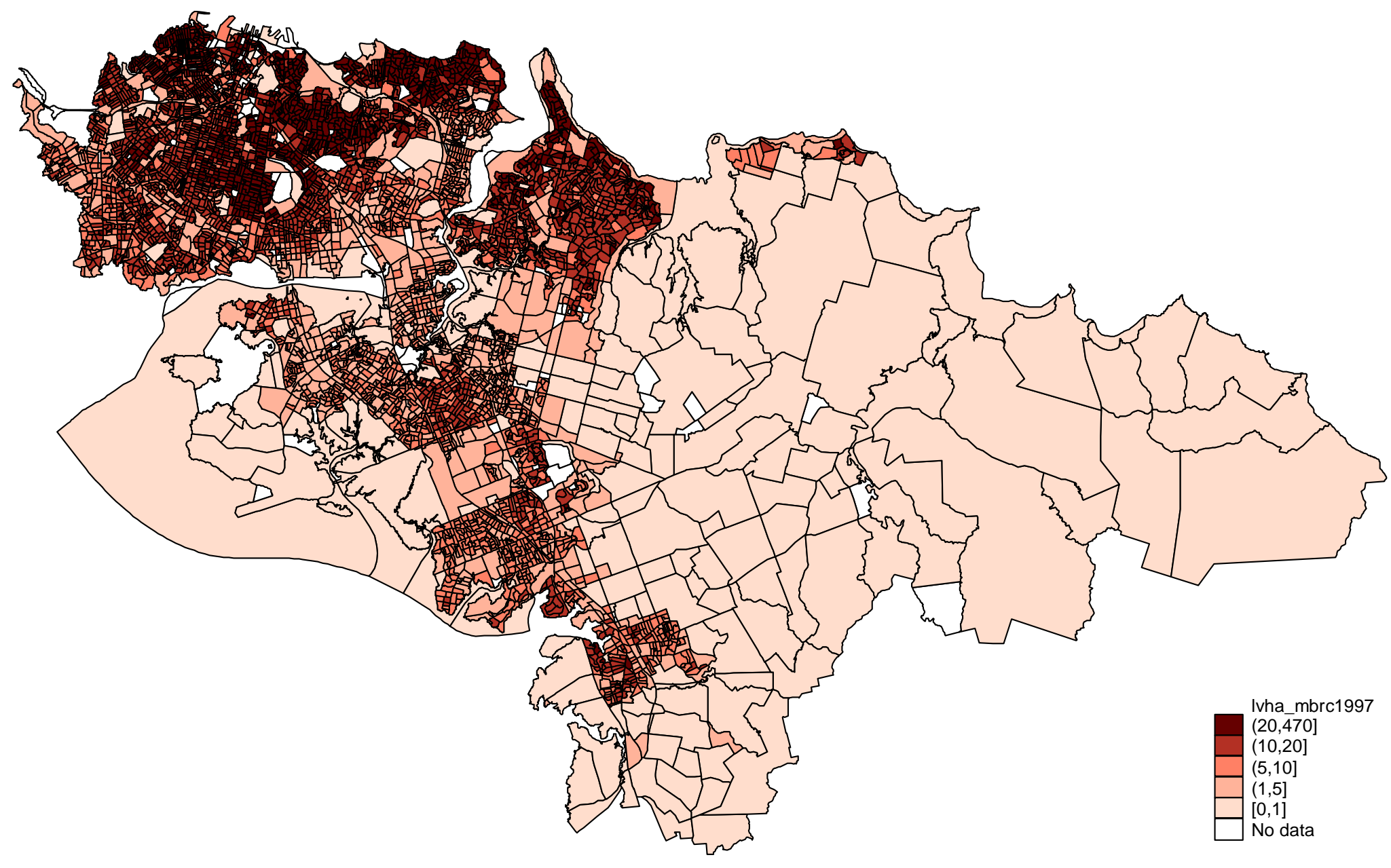

N 


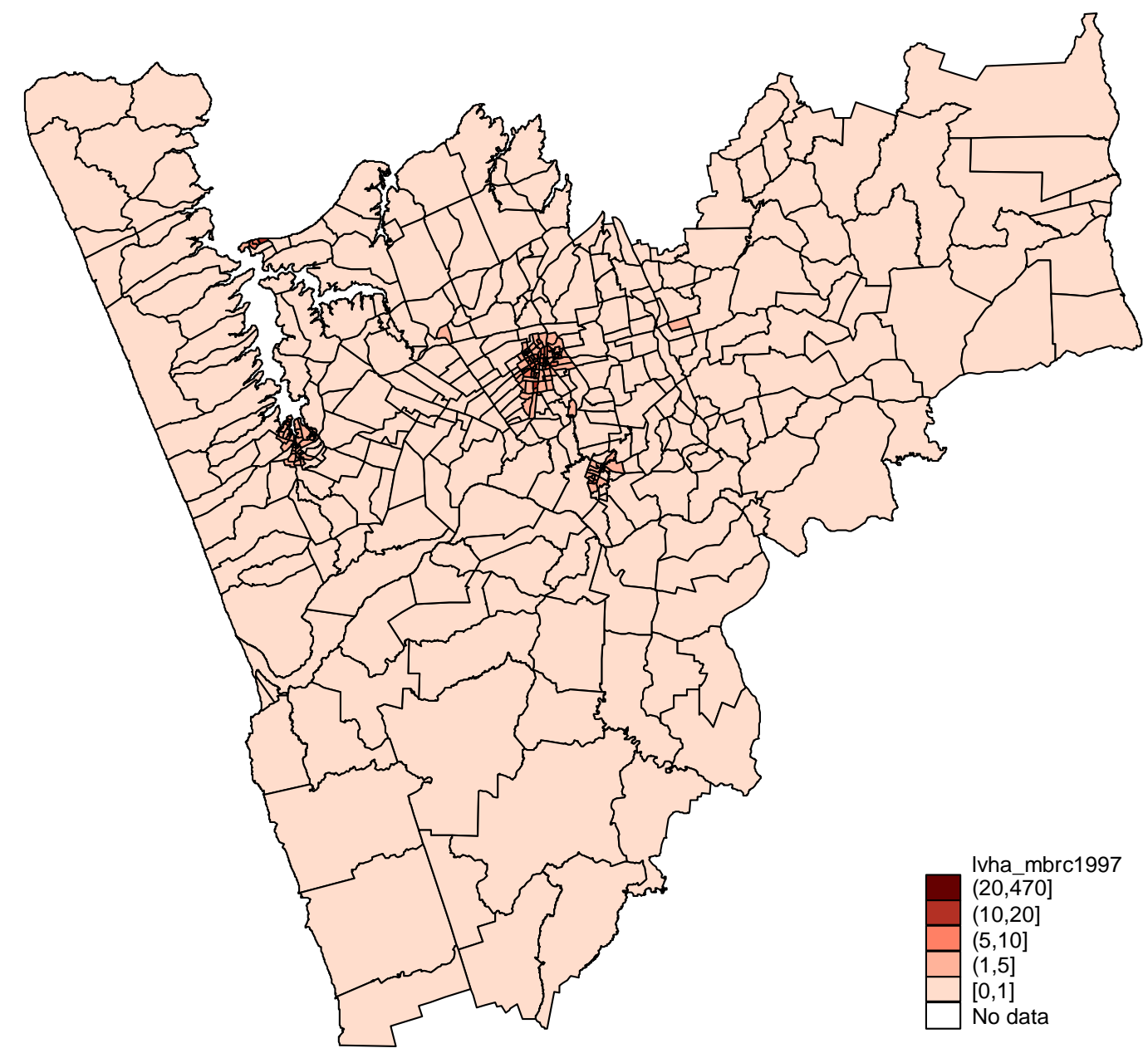




\section{Rodney District}

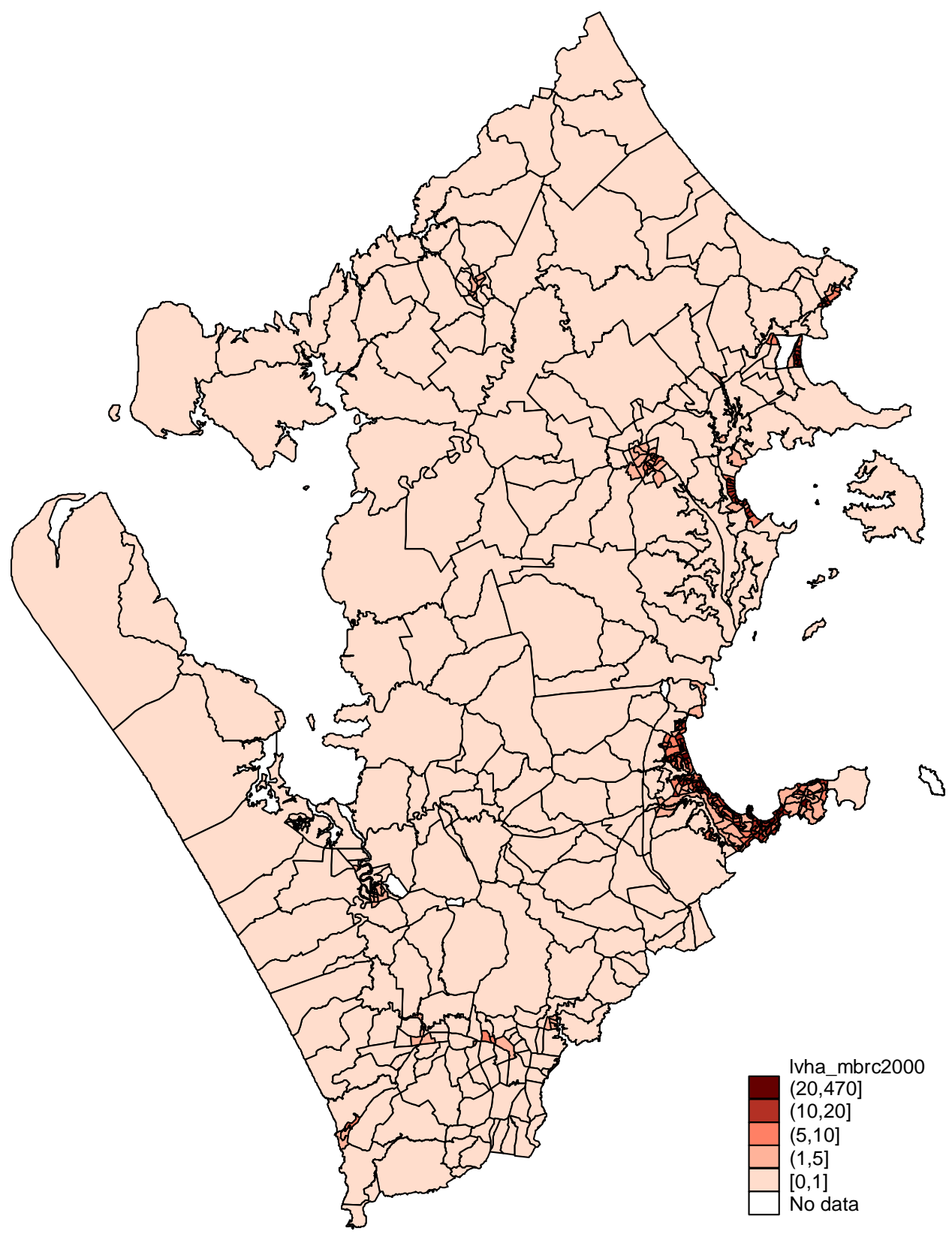


Waitakere City and North Shore City

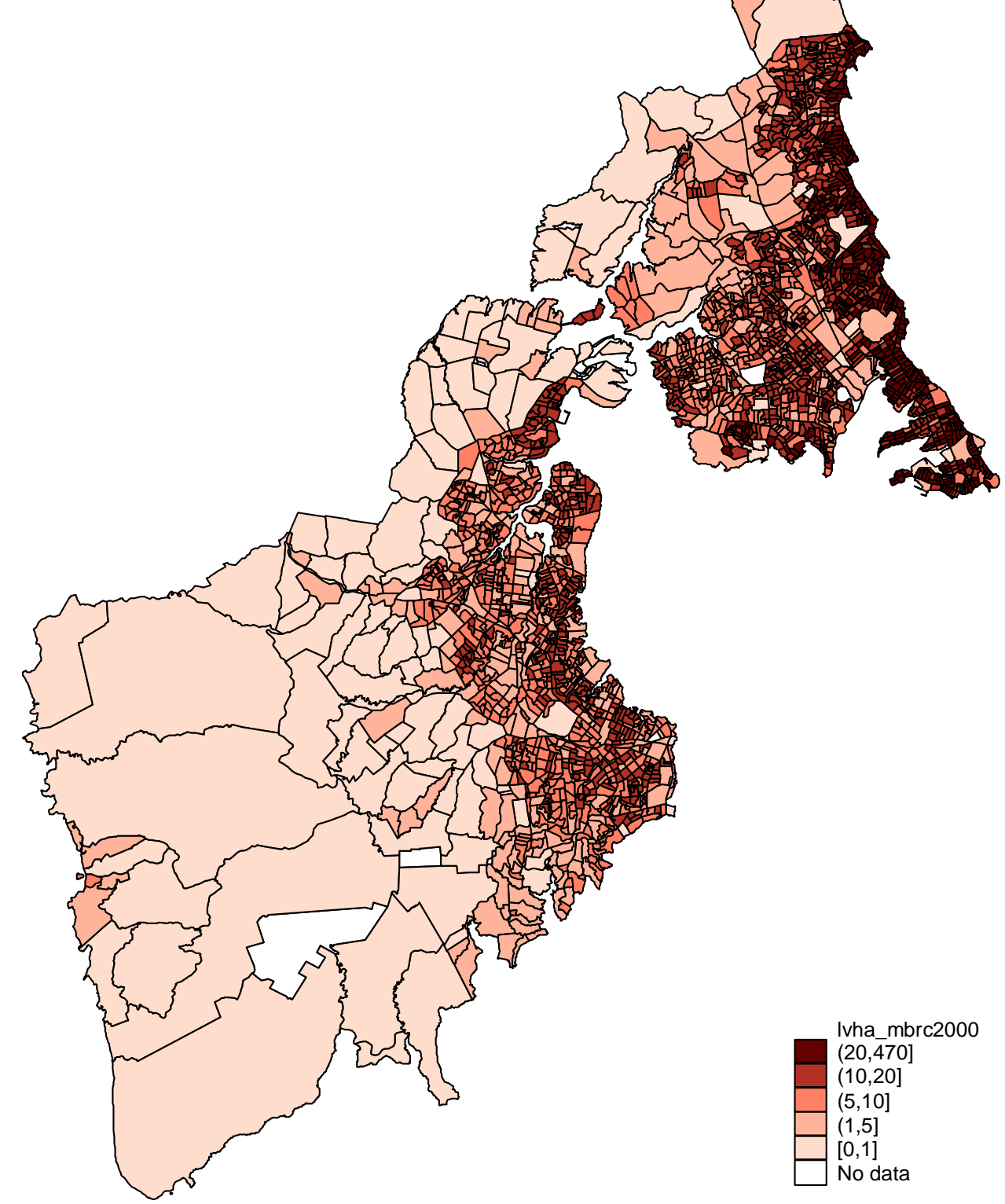


Auckland City, Manukau City and Papakura District

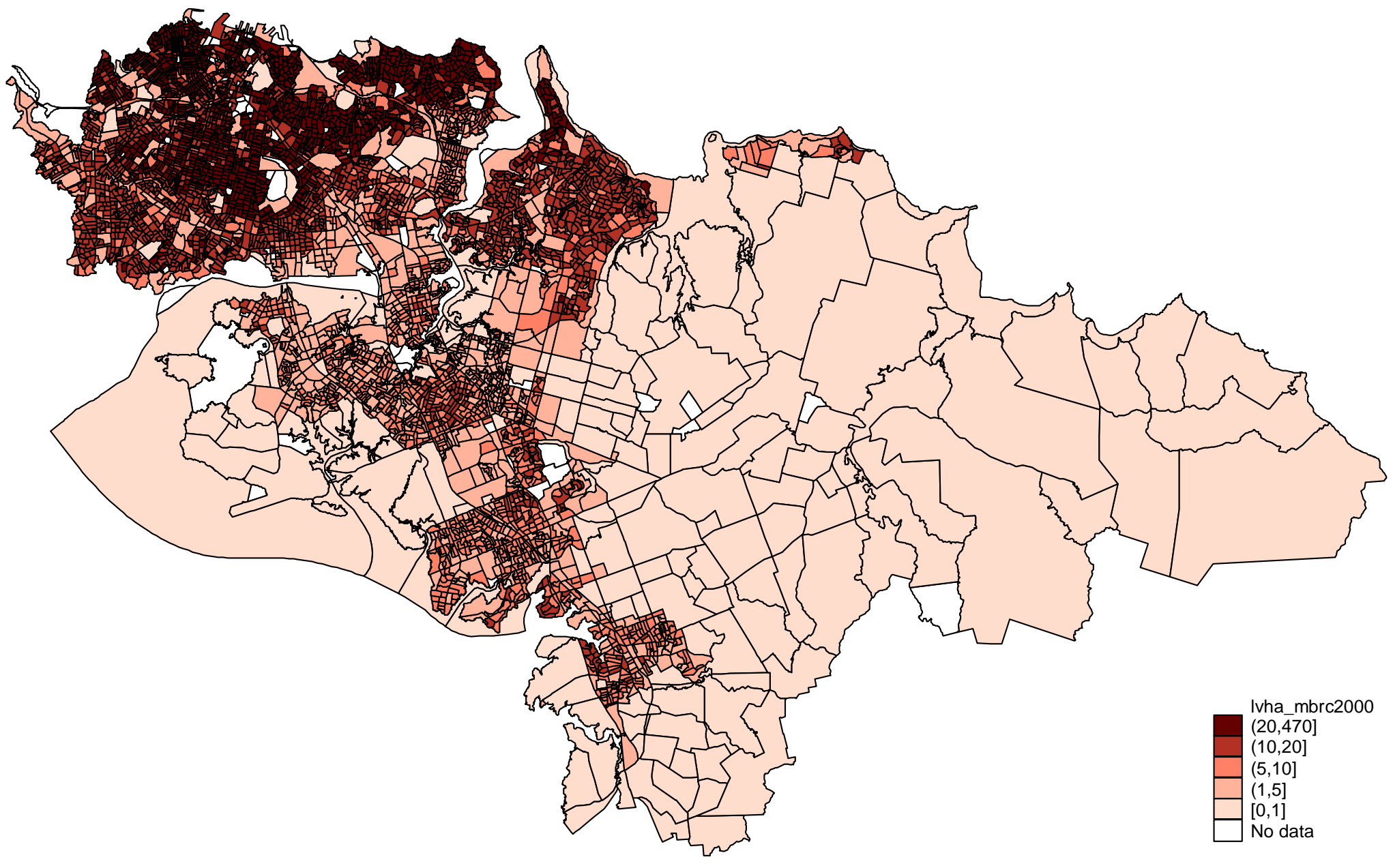

$\omega$ 


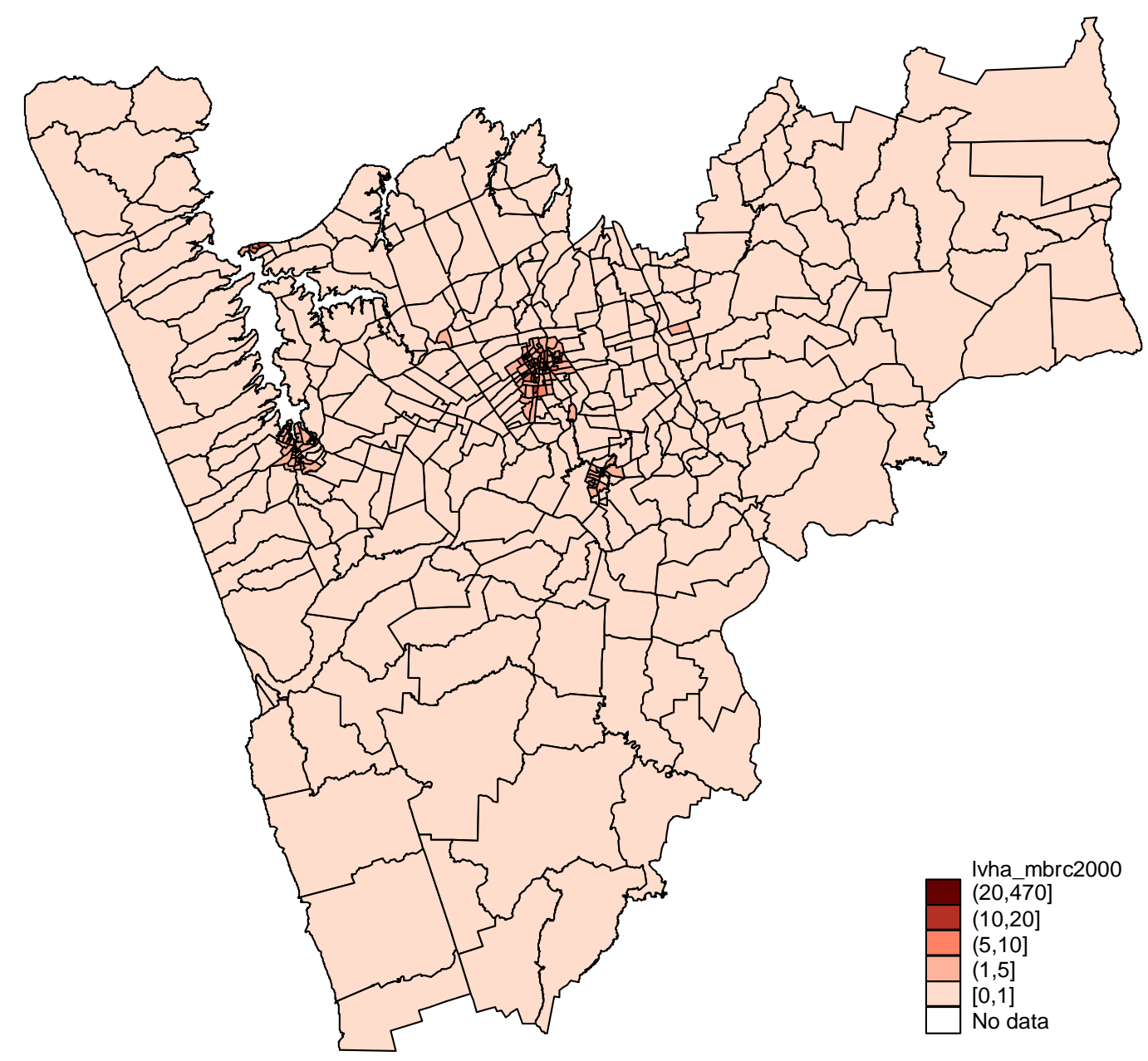




\section{Rodney District}

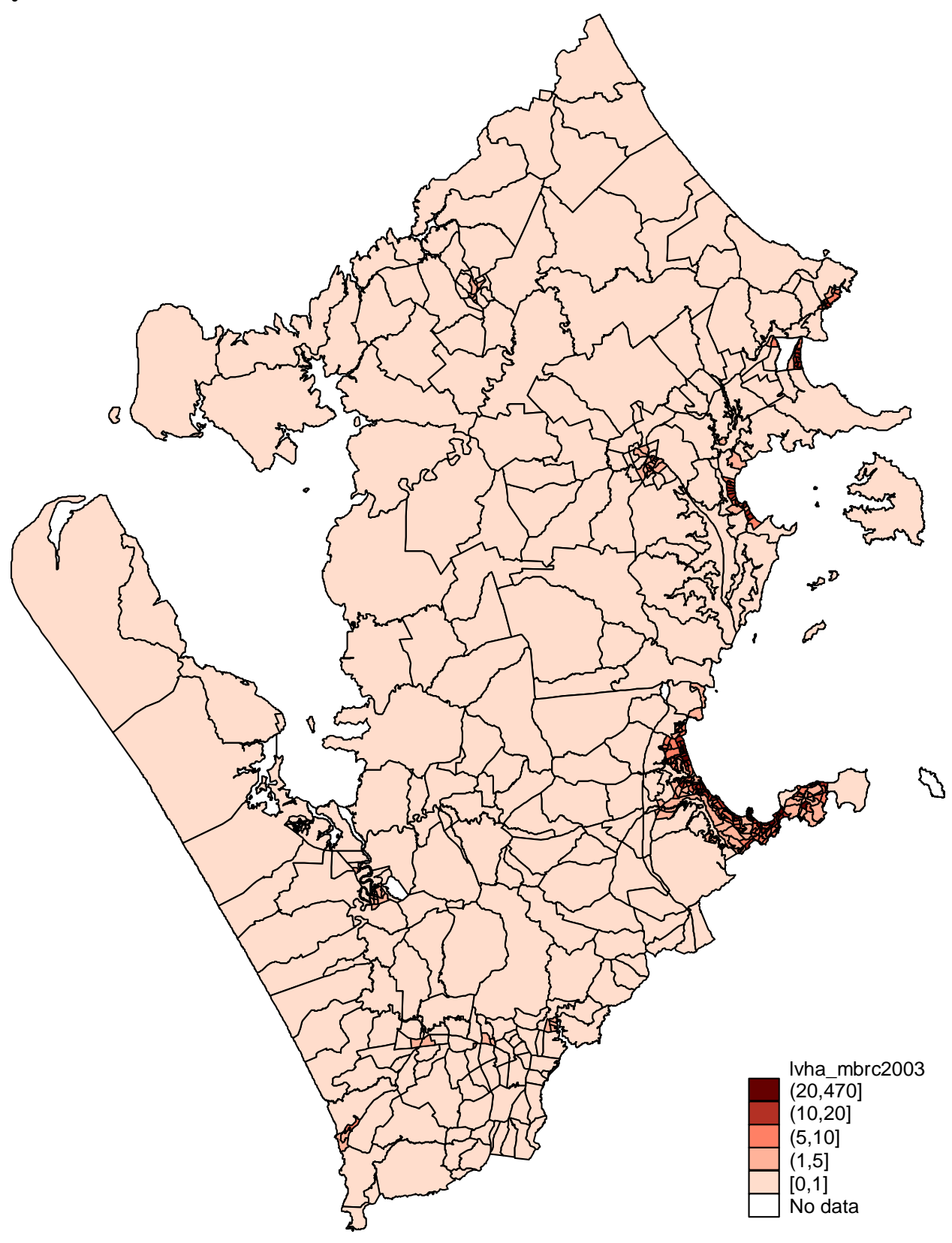




\section{Waitakere City and North Shore City}

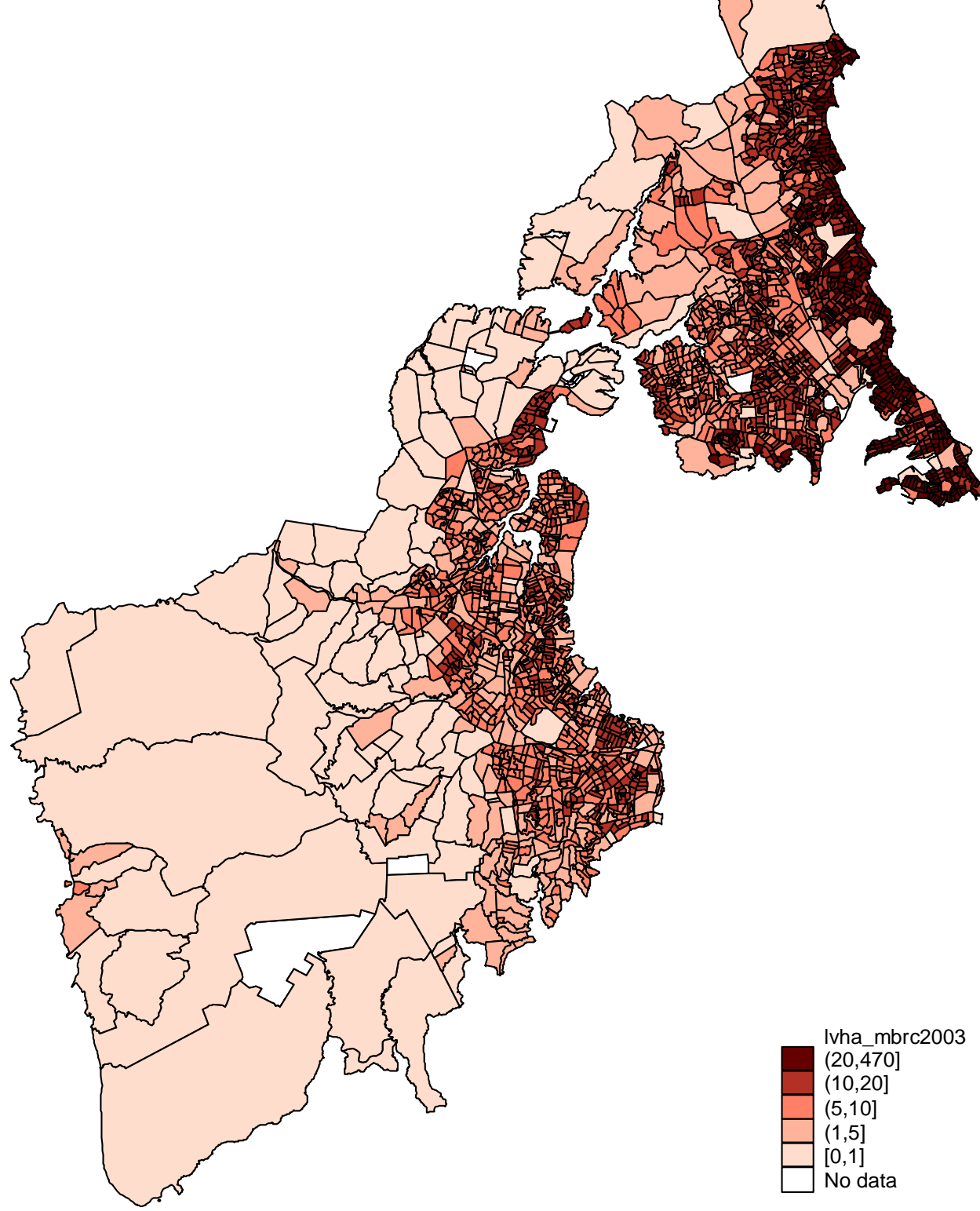


Auckland City, Manukau City and Papakura District

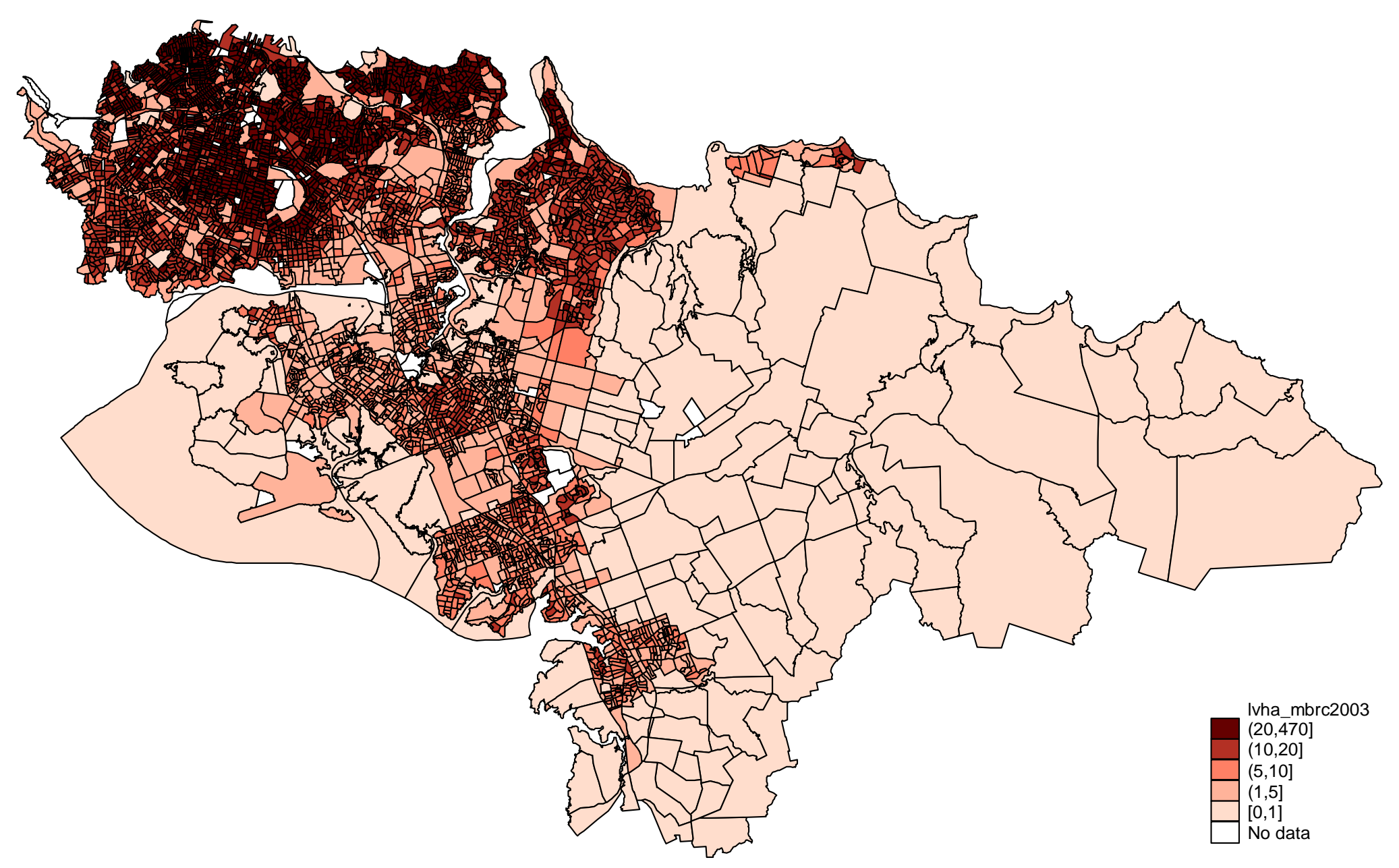




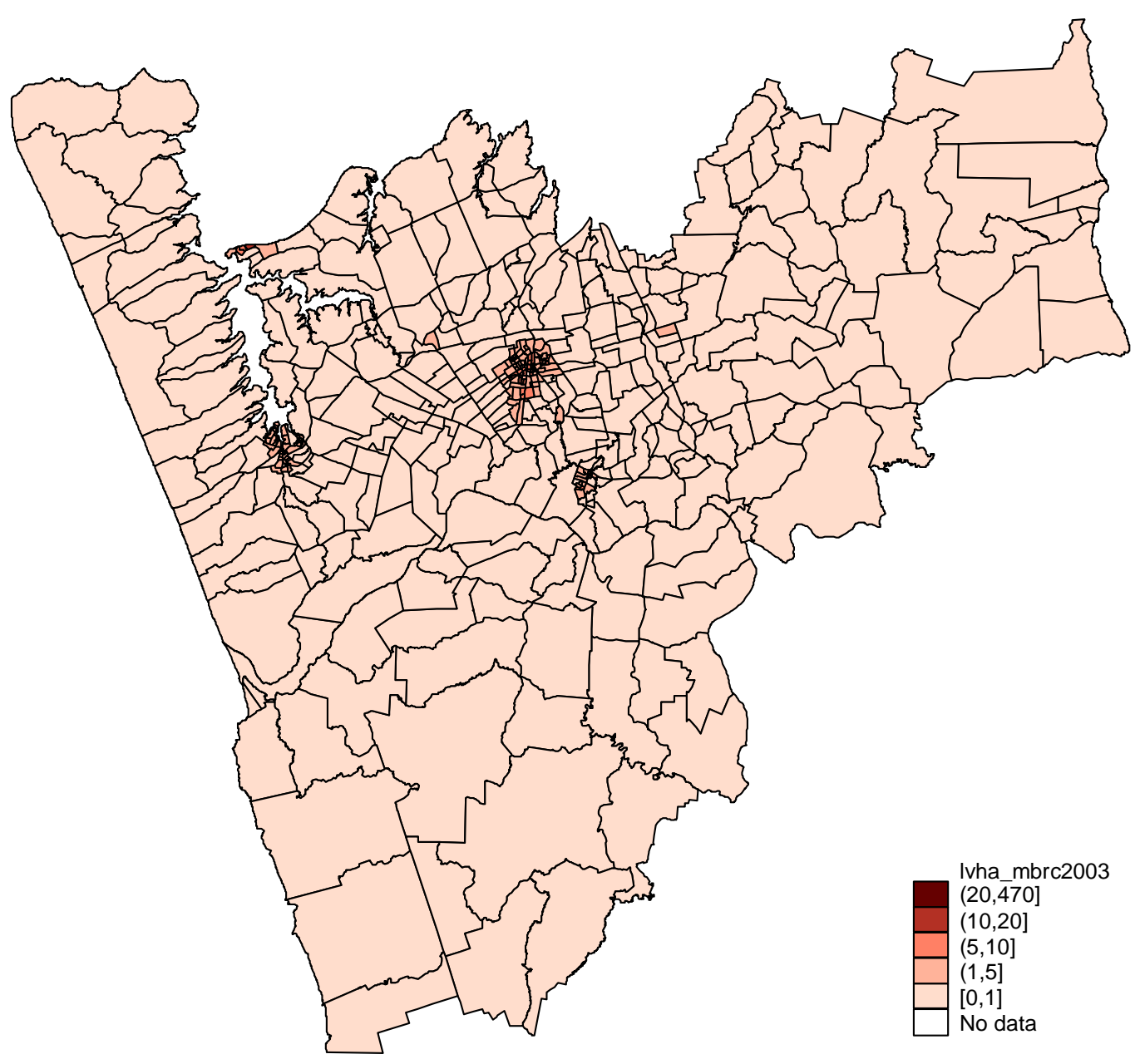




\section{$5 \quad$ Motu Working Paper Series}

All papers are available online at http://www.motu.org.nz/motu wp series.htm or by contacting Motu Economic and Public Policy Research.

07-03 Kerr, Suzi, Glen Lauder and David Fairman, “Towards Design for a Nutrient Trading Programme to Improve Water Quality in Lake Rotorua".

07-02 Lock, Kelly and Stefan Leslie, "New Zealand's Quota Management System: A History of the First 20 Years".

07-01 Grimes, Arthur and Andrew Aitken, "House Prices and Rents: Socio-Economic Impacts and Prospects".

06-09 Maani, Sholeh A., Rhema Vaithianathan and Barbara Wolf, "Inequality and Health: Is House Crowding the Link?"

06-08 Maré, David C. and Jason Timmins, "Geographic Concentration and Firm Productivity".

06-07 Grimes, Arthur; David C. Maré and Melanie Morten, "Defining Areas Linking Geographic Data in New Zealand".

06-06 Maré, David C. and Yun Liang, "Labour Market Outcomes for Young Graduates”.

06-05 Hendy, Joanna and Suzi Kerr, "Land-Use Intensity Module: Land Use in Rural New Zealand Version 1".

06-04 Hendy, Joanna; Suzi Kerr and Troy Baisden, "Greenhouse Gas Emissions Charges and Credits on Agricultural Land: What Can a Model Tell Us?"

06-03 Hall, Viv B.; C. John McDermott and James Tremewan, "The Ups and Downs of New Zealand House Prices".

06-02 McKenzie, David; John Gibson and Steven Stillman, "How Important is Selection? Experimental vs Non-Experimental Measures of the Income Gains from Migration".

06-01 Grimes, Arthur and Andrew Aitken, "Housing Supply and Price Adjustment".

05-14 Timmins, Jason, "Is Infrastructure Productive? Evaluating the Effects of Specific Infrastructure Projects on Firm Productivity within New Zealand".

05-13 Coleman, Andrew; Sylvia Dixon and David C. Maré, "Māori Economic DevelopmentGlimpses from Statistical Sources".

05-12 Maré, David C., "Concentration, Specialisation and Agglomeration of Firms in New Zealand".

05-11 Holmes, Mark J. and Arthur Grimes, "Is There Long-Run Convergence of Regional House Prices in the UK?"

05-10 Hendy, Joanna and Suzi Kerr, "Greenhouse Gas Emission Factor Module: Land Use in Rural New Zealand-Climate Version 1".

05-09 Poland, Michelle and David C. Maré, "Defining Geographic Communities".

05-08 Kerr, Suzi; Joanna Hendy, Emma Brunton and Isabelle Sin, "The Likely Regional Impacts of an Agricultural Emissions Policy in New Zealand: Preliminary Analysis".

05-07 Stillman, Steven, "Examining Changes in the Value of Rural Land in New Zealand between 1989 and 2003".

05-06 Dixon, Sylvia and David C. Maré, "Changes in the Māori Income Distribution: Evidence from the Population Census".

05-05 Sin, Isabelle and Steven Stillman, “The Geographical Mobility of Māori in New Zealand”.

05-04 Grimes, Arthur, "Regional and Industry Cycles in Australasia: Implications for a Common Currency". 
05-03 Grimes, Arthur, "Intra and Inter-Regional Industry Shocks: A New Metric with an Application to Australasian Currency Union".

05-02 Grimes, Arthur; Robert Sourell and Andrew Aitken, "Regional Variation in Rental Costs for Larger Households".

05-01 Maré, David C., "Indirect Effects of Active Labour Market Policies".

04-12 Dixon, Sylvia and David C. Maré, "Understanding Changes in Māori Incomes and Income Inequality 1997-2003".

04-11 Grimes, Arthur, "New Zealand: A Typical Australasian Economy?"

04-10 Hall, Viv and C. John McDermott, "Regional Business Cycles in New Zealand: Do They Exist? What Might Drive Them?"

04-09 Grimes, Arthur; Suzi Kerr and Andrew Aitken, "Bi-Directional Impacts of Economic, Social and Environmental Changes and the New Zealand Housing Market".

04-08 Grimes, Arthur and Andrew Aitken, "What's the Beef with House Prices? Economic Shocks and Local Housing Markets".

04-07 McMillan, John, "Quantifying Creative Destruction: Entrepreneurship and Productivity in New Zealand".

04-06 Maré, David C. and Isabelle Sin, "Māori Incomes: Investigating Differences Between Iwi”.

04-05 Kerr, Suzi; Emma Brunton and Ralph Chapman, "Policy to Encourage Carbon Sequestration in Plantation Forests".

04-04 Maré, David C., "What do Endogenous Growth Models Contribute?"

04-03 Kerr, Suzi; Joanna Hendy, Shuguang Liu and Alexander S. P. Pfaff, "Uncertainty and Carbon Policy Integrity".

04-02 Grimes, Arthur; Andrew Aitken and Suzi Kerr, "House Price Efficiency: Expectations, Sales, Symmetry".

04-01 Kerr, Suzi; Andrew Aitken and Arthur Grimes, "Land Taxes and Revenue Needs as Communities Grow and Decline: Evidence from New Zealand".

03-19 Maré, David C., "Ideas for Growth?"

03-18 Fabling, Richard and Arthur Grimes, "Insolvency and Economic Development: Regional Variation and Adjustment".

03-17 Kerr, Suzi; Susana Cardenas and Joanna Hendy, "Migration and the Environment in the Galapagos: An Analysis of Economic and Policy Incentives Driving Migration, Potential Impacts from Migration Control, and Potential Policies to Reduce Migration Pressure”.

03-16 Hyslop, Dean R. and David C. Maré, “Understanding New Zealand's Changing Income Distribution 1983-98: A Semiparametric Analysis".

03-15 Kerr, Suzi, "Indigenous Forests and Forest Sink Policy in New Zealand”.

03-14 Hall, Viv and Angela Huang, "Would Adopting the US Dollar Have Led to Improved Inflation, Output and Trade Balances for New Zealand in the 1990s?"

03-13 Ballantyne, Suzie; Simon Chapple, David C. Maré and Jason Timmins, "Movement into and out of Child Poverty in New Zealand: Results from the Linked Income Supplement".

03-12 Kerr, Suzi, "Efficient Contracts for Carbon Credits from Reforestation Projects".

03-11 Lattimore, Ralph, "Long Run Trends in New Zealand Industry Assistance”.

03-10 Grimes, Arthur, "Economic Growth and the Size \& Structure of Government: Implications for New Zealand”.

03-09 Grimes, Arthur; Suzi Kerr and Andrew Aitken, "Housing and Economic Adjustment”.

03-07 Maré, David C. and Jason Timmins, "Moving to Jobs". 
03-06 Kerr, Suzi; Shuguang Liu, Alexander S. P. Pfaff and R. Flint Hughes, "Carbon Dynamics and Land-Use Choices: Building a Regional-Scale Multidisciplinary Model".

03-05 Kerr, Suzi, "Motu, Excellence in Economic Research and the Challenges of "Human Dimensions' Research".

03-04 Kerr, Suzi and Catherine Leining, "Joint Implementation in Climate Change Policy".

03-03 Gibson, John, "Do Lower Expected Wage Benefits Explain Ethnic Gaps in Job-Related Training? Evidence from New Zealand".

03-02 Kerr, Suzi; Richard G. Newell and James N. Sanchirico, "Evaluating the New Zealand Individual Transferable Quota Market for Fisheries Management".

03-01 Kerr, Suzi, "Allocating Risks in a Domestic Greenhouse Gas Trading System”. 